\title{
Iron Complexation to Histone Deacetylase Inhibitors SAHA and LAQ824 in PEGylated Liposomes Can Considerably Improve Pharmacokinetics in Rats
}

\author{
Yan Wang, Sheng Tu, Dana Steffen, May P. Xiong \\ School of Pharmacy, University of Wisconsin - Madison, Madison, Wisconsin, USA \\ Received, December 16, 2014; Accepted, December 24, 2014; Published, December 31 2014.
}

\begin{abstract}
PURPOSE. The formulation of histone deacetylase inhibitors (HDACi) is challenging due to poor water solubility and rapid elimination of drugs in vivo. This study investigated the effects of complexing iron $\left(\mathrm{Fe}^{3+}\right)$ to the HDACi suberoylanilide hydroxamic acid (SAHA) and LAQ824 (LAQ) prior to their encapsulation into PEGylated liposomes, and investigated whether this technique could improve drug solubility, in vitro release and in vivo pharmacokinetic (PK) properties. METHODS. The reaction stoichiometry, binding constants and solubility were measured for Fe complexes of SAHA and LAQ. The complexes were passively encapsulated into PEGylated liposomes and characterized by size distribution, zeta-potential, encapsulation efficiency (EE), and in vitro drug release studies. PC-3 cells were used to verify the in vitro anticancer activity of the formulations. In vivo pharmacokinetic properties of liposomal LAQ-Fe (L-LAQ-Fe) was evaluated in rats. RESULTS. SAHA and LAQ form complexes with $\mathrm{Fe}$ at 1:1 stoichiometric ratio, with a binding constant on the order of $10^{4} \mathrm{M}^{-1}$. Fe complexation improved the aqueous solubility and the liposomal encapsulation efficiency of SAHA and LAQ (29-35\% EE, final drug concentration $>1 \mathrm{mM}$ ). Liposomal encapsulated complexes (L-HDACi-Fe) exhibited sustained in vitro release properties compared to L-HDACi but cytotoxicity on PC-3 cells was comparable to free drugs. The PK of L-LAQ-Fe revealed 15 -fold improvement in the plasma $t_{1 / 2}(12.11 \mathrm{~h})$ and 211 -fold improvement in the $\operatorname{AUC}_{\infty}(105.7 \mu \mathrm{g} \cdot \mathrm{h} / \mathrm{ml})$ compared to free LAQ $(0.79 \mathrm{~h}, 0.5 \mu \mathrm{g} \cdot \mathrm{h} / \mathrm{ml})$. Similarly, the plasma $t_{1 / 2}$ of Fe was determined to be $11.83 \mathrm{~h}$ in a separate experiment using radioactive Fe-59. The majority of Fe-59 activity was found in liver and spleen of rats and correlates with liposomal uptake by the mononuclear phagocyte system. CONCLUSIONS. We have demonstrated that encapsulation of Fe complexes of HDACi into PEGylated liposomes can improve overall drug aqueous solubility, in vitro release and in vivo pharmacokinetic properties.
\end{abstract}

This article is open to POST-PUBLICATION REVIEW. Registered readers (see "For Readers") may comment by clicking on ABSTRACT on the issue's contents page.

\section{INTRODUCTION}

Histone deacetylases (HDACs) are a group of enzymes responsible for removing acetyl groups from lysine residues of histones; this causes the chromatin around histones to condense and limits access to the gene transcription machinery (1). There are at least five classes of HDACs responsible for turning genes on and off, but they all fall under two categories of being either zinc-dependent or $\mathrm{NAD}^{+}-$ dependent to function properly $(2,3)$. HDAC overexpression and aberrant recruitment to promoters of genes implicated in differentiation and tumor suppression are recognized as important mechanisms of cancer cell survival (4). The suppression of HDAC activity via small molecule HDAC inhibitors (HDACi) is an important therapeutic strategy in cancer treatment, with several studies having shown good correlation between the anti-tumor effects of HDACi with restoration of expression of genes involved in differentiation and tumor suppression $(5,6)$. Recent studies have also demonstrated that the anticancer properties of HDACi were not limited to their effect on transcription but that HDACi can influence diverse cellular pathways, leading to cell cycle arrest, apoptosis, cell differentiation, autophagy, and antiangiogenic effects (7). Most important, it has been reported that normal cells are significantly less sensitive to the effects induced by HDACi (8),

Corresponding Author: May P. Xiong, 777 Highland Avenue, Madison, USA; Email: may.xiong@wisc.edu 
which could help minimize non-specific toxicities often observed with the majority of systemically administered chemotherapeutic agents.

Two promising HDACi targeting mainly zincdependent HDACs are SAHA (marketed as Zolinza $^{\text {TM }}$ by Merck) and LAQ (9). SAHA was approved by FDA in 2006 for the treatment of cutaneous T-cell lymphoma (CTCL) and is still being investigated in clinical trials either as a single agent or in combination with other agents for the treatment of various malignancies (9). LAQ was developed by Novartis and has completed phase I clinical trials in hematologic and solid malignancies (10). Although SAHA was approved for oral administration, the formulation of both SAHA and LAQ for intravenous (I.V.) administration remains a challenge due to their limited aqueous solubility and poor PK in vivo $(10,11)$. To address these challenges, a recent study has reported on the use of poly(ethylene glycol)-b-poly(DL-lactic acid) (PEGb-PLA) micelles to encapsulate SAHA to improve both solubility and PK of the drug (12). In another example, LAQ was successfully entrapped into targeted immunoliposomes via formation of a complex between LAQ and a polymer, polyanionic polyol sucrose octasulfate (SOS), resulting in prolonged $\mathrm{PK}$ and improved antitumor properties (13).

The utilization of transition metals such as $\mathrm{Cu}^{2+}$, $\mathrm{Mn}^{2+}, \mathrm{Zn}^{2+}$ and $\mathrm{Co}^{2+}$ has been studied in the gradient loading of a few drugs in liposome formulations (1416). The formation of a metal-drug complex is also able to reduce the drug release rate from liposomes both in vitro and in vivo $(15,16)$. SAHA and LAQ possess hydroxamic acid moieties in their chemical structures, which are well-known to bind Fe since many siderophores utilized by bacteria and fungi possess hydroxamic acid moieties for Fe chelation (17). In this work, we investigated whether formation of a complex between ferric iron $\left(\mathrm{Fe}^{3+}\right)$ and SAHA and LAQ could be used to increase entrapment of drugs into liposomes. We hypothesized that the resulting complexes should improve aqueous solubility of the drugs, leading to slower release from liposomes, and enhanced pharmacokinetics.

\section{MATERIALS AND METHODS}

\section{Materials}

SAHA was purchased from LC Laboratories (Woburn, MA). LAQ was purchased from Selleck
Chemicals (Houston, TX). Ferric chloride hexahydrate, cholesterol, 3-(2-pyridyl)-5,6diphenyl-1,2,4-triazine- $p, p$ '-disulfonic acid sodium salt (ferrozine), sodium ascorbate, resazurin sodium salt were purchased from Sigma-Aldrich (St. Louis, MO). Dipalmitoylphophatidylcholine (DPPC) and dipalmitoylphosphatidylethanolamine-N-[methoxy (polyethylene glycol)-2000] (DPPE-PEG ${ }_{2000}$ ) were purchased from NOF America Corporation (White Plains, NY). Radioactive iron-59 (Fe-59) was purchased from PerkinElmer (Waltham, MA) in the form of $\mathrm{FeCl}_{3}$, with specific activity $>5 \mathrm{Ci} / \mathrm{g}$. SnakeSkin dialysis tubing (10,000 MWCO), Dulbecco's modified eagle medium (DMEM), 0.05\% trypsin/EDTA solution, heat-inactivated fetal bovine serum (FBS), penicillin-streptomycin solution $(100 \times)$, L-glutamine solution $(100 \times)$ and nonessential amino acids solution (100X) were purchased from ThermoFisher Scientific (Waltham, MA). The fluorophore 2',7'-dichlorodihydrofluorescein diacetate $\left(\mathrm{H}_{2}\right.$ DCFDA) was purchased from Life Technologies (Grand Island, NY). Annexin V-FITC apoptosis detection kit was purchased from BD Biosciences (San Jose, CA).

\section{HPLC methods}

A Shimadzu UFLC system equipped with $150 \times 4.6$ mm Hypersil BDS C-18 column was used for quantitative analysis of SAHA and LAQ. Mobile phase A contained HPLC grade water with $1 \%$ acetic acid, and mobile phase B contained HPLC grade acetonitrile with $1 \%$ acetic acid. SAHA was eluted with $20 \%$ mobile phase B at a flow rate of $1 \mathrm{ml} / \mathrm{min}$, with retention time of about $6.8 \mathrm{~min}$ and $\mathrm{UV}$ detection at $260 \mathrm{~nm}$. LAQ was eluted with $25 \%$ mobile phase $B$ at a flow rate of $1 \mathrm{ml} / \mathrm{min}$, with retention time of about $7.5 \mathrm{~min}$ and UV detection at $280 \mathrm{~nm}$. Peak areas of known drug concentrations were integrated to generate linear calibration curves for calculation of unknown SAHA/LAQ samples. The lower limit of quantification (defined as the lowest concentration on the standard curve that can be quantified with accuracy within $20 \%$ of nominal values and precision not exceeding $20 \%$ of the column volume) for SAHA was $1.0 \mu \mathrm{g} / \mathrm{ml}$ and for LAQ this limit was $0.2 \mu \mathrm{g} / \mathrm{ml}$. Five-point calibration curves for SAHA in the range $1-200 \mu \mathrm{g} / \mathrm{ml}$ and LAQ in the range $0.2-100 \mu \mathrm{g} / \mathrm{ml}$ were both linear with $\mathrm{r}^{2} \geq$ 0.999 . 


\section{Solubility studies}

The solubility of SAHA/LAQ was measured at various $\mathrm{pHs}$ by adding excess $\mathrm{SAHA} / \mathrm{LAQ}$ to either pH 2 solutions (ca. $10 \mathrm{mM} \mathrm{HCl}$ ), pH 6 deionized water $\left(\mathrm{ddH}_{2} \mathrm{O}\right), \mathrm{pH} 12$ solutions (ca. $\left.30 \mathrm{mM} \mathrm{NaOH}\right)$ or $\mathrm{FeCl}_{3}$ solutions $\left(50 \mathrm{mM} \mathrm{FeCl}_{3}\right.$, acidified with 10 $\mathrm{mM} \mathrm{HCl}$ to ca. $\mathrm{pH} 2$ to avoid $\mathrm{Fe}^{3+}$ precipitation). Drugs were allowed to equilibrate in the solutions by rotating for $48 \mathrm{~h}$ at $25^{\circ} \mathrm{C}$. After equilibration, the solutions were filtered through $0.2 \mu \mathrm{m}$ nylon filters to remove undissolved solids and characterized by HPLC to assay for the maximum concentration of SAHA/LAQ solubilized under the various conditions.

\section{HDACi-Fe stoichiometry}

Formation of HDACi-Fe complexes could be visually assessed by the appearance of a dark purple color upon complexation for both SAHA-Fe and LAQ-Fe. The UV-Vis absorption spectrum was monitored over a broad range of wavelength using a SpectraMax Plus spectrophotometer (Molecular Devices). Peak absorbance at $500 \mathrm{~nm}$ was used to quantify complex concentration. The method of continuous variation was used to determine the reaction stoichiometry between SAHA/LAQ and Fe (18). For example, SAHA and $\mathrm{FeCl}_{3}$ were mixed in $10 \mathrm{mM} \mathrm{HCl}$ solutions at different molar ratios while keeping the total mole concentration of SAHA and $\mathrm{Fe}$ constant at $0.4 \mathrm{mM}$. Reaction mixtures were measured at $500 \mathrm{~nm}$, with absorbance directly correlating to increasing presence of $\mathrm{HDACi}-\mathrm{Fe}$ complexes; this absorbance was then plotted with respect to mole percentage of drug to generate a maximum curve. The point of intersection from the tangents of the curves from each side was used to determine the theoretical binding stoichiometry of SAHA or LAQ to Fe.

\section{HDACi-Fe binding constants}

The binding constants were determined according to a method described in the literature (19). For example, a stock solution of $\mathrm{FeCl}_{3}(40 \mathrm{mM})$ was diluted with deionized water to desired final concentrations of $0.033,0.05,0.1,0.2$ and $2 \mathrm{mM}$. Next, $0.5 \mathrm{ml}$ of each of these $\mathrm{FeCl}_{3}$ dilutions was added to $0.5 \mathrm{ml}$ of SAHA/LAQ solution $(0.05$ $\mathrm{mg} / \mathrm{ml}$ ). After vortexing and incubating solutions for $10 \mathrm{~min}$ at room temperature, absorbance was measured at $500 \mathrm{~nm}$. The blank used was a solution of SAHA/LAQ $(0.05 \mathrm{mg} / \mathrm{ml})$ without addition of $\mathrm{FeCl}_{3}$. The plots of $1 /($ absorbance) with respect to
$1 /$ (Fe concentration) gave a linear relationship for both SAHA and LAQ; for each drug, the binding constant $\left(K: \mathrm{M}^{-1}\right)$ was calculated by taking the ratio of the intercept (where the line crosses the vertical axis) to the slope. Details of the mathematical equations utilized to calculate the binding constants are described in Supplementary Information.

\section{Preparation of HDACi-Fe and HDACi into liposomes}

Liposomal HDACi-Fe was prepared via the hydration method. More specifically, DPPC, cholesterol and DPPE-PEG 2000 at molar ratios of 80:50:4 $(\mu \mathrm{M})$ were dissolved in chloroform in a round bottom flask, and the organic solvent was evaporated on a rotary-evaporator. SAHA was dissolved in $1 \mathrm{ml}$ methanol $(5 \mathrm{mg} / \mathrm{ml}, 19 \mathrm{mM})$ and mixed with $1 \mathrm{ml}$ of $19 \mathrm{mM} \mathrm{FeCl}_{3}$ aqueous solution to yield a 1:1 SAHA-Fe complex mixture in methanol-water. This SAHA-Fe complex mixture was used to "hydrate" the lipids at $55^{\circ} \mathrm{C}$ for $30 \mathrm{~min}$ with vigorous rotation until all lipids solubilized into the mixture. Methanol was slowly evaporated from the mixture with the rotary-evaporator at $55^{\circ} \mathrm{C}$, and multilamellar vesicles (MLV) encapsulating SAHAFe spontaneously formed during this process. The MLVs were then subjected to 11 extrusions through a $100 \mathrm{~nm}$ polycarbonate membrane fitted into a miniextruder set (Avanti Polar Lipids) to form large unilamellar vesicles (LUV). Liposomal SAHA-Fe complex (L-SAHA-Fe) was separated from unencapsulated SAHA-Fe complex by eluting through a size exclusion PD-10 column (GE Healthcare, Pittsburgh, PA); L-LAQ-Fe was similarly prepared. For the preparation of L-SAHA, L-LAQ or L-Fe, the same composition of lipids was dissolved in chloroform and dried with rotary-evaporator. SAHA was dissolved in $1 \mathrm{ml} \mathrm{pH} 12 \mathrm{NaOH}$ solution (4 $\mathrm{mg} / \mathrm{ml}$ ) and this solution was used to hydrate the dried lipids in a $55^{\circ} \mathrm{C}$ water bath for $30 \mathrm{~min}$. For the preparation of L-LAQ, LAQ was dissolved in $1 \mathrm{ml}$ $\mathrm{pH} 2$ solution $(4 \mathrm{mg} / \mathrm{ml})$ and this was used to rehydrate lipids. For the preparation of L-Fe, $1 \mathrm{ml} 50$ $\mathrm{mM} \mathrm{FeCl}{ }_{3}$ solution was used directly to rehydrate lipids. The resulting MLVs from all preparations were extruded 11 times through $100 \mathrm{~nm}$ membranes to form LUV liposomes around $100 \mathrm{~nm}$, followed by cleanup through a PD-10 column to obtain the final L-SAHA, L-LAQ, or L-Fe. The final lipid concentration for each formulation was ca. $60 \mathrm{mg} / \mathrm{ml}$. 
Quantifying Fe concentration in liposomes

Fe concentration in liposome samples (L-HDACi-Fe and $\mathrm{L}-\mathrm{Fe}$ ) was measured with a colorimetric assay (20). Briefly, $10 \mu 1$ aliquot of each sample was mixed with $50 \mu 1$ isopropyl alcohol to break apart the liposomes and subsequently diluted with $940 \mu \mathrm{l}$ of $10 \mathrm{mM} \mathrm{HCl}$ solution to release Fe. Next, $100 \mu \mathrm{l}$ sodium ascorbate solution $(1 \mathrm{mg} / \mathrm{ml})$ was added to $500 \mu \mathrm{l}$ of this Fe-containing solution to reduce iron from ferric $[\mathrm{Fe}(\mathrm{III})]$ to ferrous $[\mathrm{Fe}(\mathrm{II})]$ form. The resulting solution was then mixed with $400 \mu \mathrm{l}$ ferrozine solution $(0.5 \mathrm{mg} / \mathrm{ml})$ to generate a dark blue complex of ferrozine-Fe(II). The concentration of iron was calculated by measuring the absorption at $590 \mathrm{~nm}$ and fitting into a linear calibration curve generated from standard samples.

\section{Physicochemical characterization of liposomes}

Size distribution and zeta potential of liposomes were measured using a Zetasizer Nano ZS (Malvern Instruments, UK). Size distribution was reported as Z-average diameter along with polydispersity index (PDI). The encapsulation efficiency (EE) of HDACi$\mathrm{Fe}$ and HDACi in liposomes was calculated by the following equation:

$$
\begin{gathered}
\mathrm{EE}=100 \times(\text { Dilution Factor }) \times(\text { Encapsulated Drug } \\
\text { Concentration }) /(\text { Initial Drug Concentration }) \%
\end{gathered}
$$

Dilution factor corresponds to the fold increase in volume, which is about 2.5, following elution of samples through the size-exclusion column. Encapsulated drug concentration was measured by dissolving an aliquot of the liposome sample with isopropyl alcohol to release the drug from the complex prior to HPLC analysis. To calculate the EE of L-Fe, both initial iron concentration and encapsulated iron concentration were measured with the colorimetric iron assay. Three separate characterizations were conducted for each formulation and results are reported as mean \pm standard deviation (SD).

\section{In vitro drug release study}

For in vitro release studies, $2 \mathrm{ml}$ liposome formulation was sealed in dialysis membrane (MWCO 10,000) and dialyzed against $1 \mathrm{~L} \mathrm{pH} 7.4$ PBS buffer at $37^{\circ} \mathrm{C}$. The dialysis buffer was refreshed every $12 \mathrm{~h}$ to mimic sink conditions; for SAHA, the release study lasted $24 \mathrm{~h}$ and for LAQ, the release study lasted 7 days. At indicated time points, $20 \mu \mathrm{l}$ aliquot of liposome sample was removed from the dialysis membrane to assay for remaining SAHA or LAQ via HPLC; for L-SAHA$\mathrm{Fe}, \mathrm{L}-\mathrm{LAQ}-\mathrm{Fe}$ and L-Fe, $10 \mu \mathrm{l}$ aliquot was also taken and assayed for remaining $\mathrm{Fe}$ via the colorimetric method as described above. Results are reported as percentage cumulative release (mean $\pm \mathrm{SD}, \mathrm{n}=3$ ).

\section{Cytotoxicity}

The PC-3 human prostate cancer cell line was obtained from American Type Culture Collection (ATCC, Rockville, MD). Cells were cultured at $37^{\circ} \mathrm{C} / 5 \% \mathrm{CO}_{2}$ in DMEM supplemented with $10 \%$ (v/v) heat-inactivated FBS, $2 \mathrm{mM}$ L-glutamine, 100 I.U./ml penicillin, $100 \mu \mathrm{g} / \mathrm{ml}$ streptomycin and MEM non-essential amino acids. Cells were seeded into 96-well plates at a density of 5,000 cell/well and allowed to adhere for $24 \mathrm{~h}$ prior to the treatments. Cells were treated with serial dilutions of either SAHA, L-SAHA, SAHA-Fe, L-SAHA-Fe, LAQ, LLAQ, LAQ-Fe, L-LAQ-Fe, $\mathrm{FeCl}_{3}$ or L-Fe for $72 \mathrm{~h}$ before measuring cell viability with the metabolismbased resazurin assay (21). More specifically, the substrate resazurin was dissolved in cell culture medium at a concentration of $44 \mu \mathrm{M}$, added to each well and incubated in a $37^{\circ} \mathrm{C} / 5 \% \mathrm{CO}_{2}$ incubator for $1 \mathrm{~h}$. The fluorescence in each well was read with a SpectraMax Gemini EM microplate reader (Molecular Devices) by excitation at $560 \mathrm{~nm}$ and emission at 590. Readings from wells without cells were used as blanks $\left(\mathrm{E}_{\text {blank }}\right)$. The readings taken from control cells without treatment $\left(\mathrm{E}_{\text {control }}\right)$ represented $100 \%$ cell viability. The viability of treated cells at each concentration was calculated by the following equation (mean $\pm S D, n=4$ ):

$$
\begin{gathered}
\text { Cell Viability }=100 \times\left(E_{\text {sample }}-E_{\text {blank }}\right) /\left(E_{\text {control }}-\right. \\
\left.E_{\text {blank }}\right) \%
\end{gathered}
$$

For data analysis, the $I C_{50}$ values of each treatment was calculated by fitting the cell viability $\log$ (concentration) data to a nonlinear logarithm curve with GraphPad Prism 5.0 software, and reported as mean $\pm \mathrm{SD}$ from three separate experiments.

\section{Reactive oxygen species study}

Intracellular levels of reactive oxygen species (ROS) were quantified with the substrate $\mathrm{H}_{2}$ DCFDA (22). Briefly, PC-3 cells were seeded into 96-well plates at a density of 25,000 cell/well and allowed to adhere overnight. Afterwards cells were incubated with 100 $\mu 1$ of $25 \mu \mathrm{M} \mathrm{H}_{2}$ DCFDA in PBS buffer for $30 \mathrm{~min}$. 
The cells were washed with PBS to remove extracellular $\mathrm{H}_{2}$ DCFDA prior to addition of the various formulations (suspended in cell culture medium) at $1 \mu \mathrm{M}$ and $10 \mu \mathrm{M}$ final concentrations. Upon cleavage of the acetate groups by intracellular esterases and oxidation by ROS, the nonfluorescent $\mathrm{H}_{2}$ DCFDA is converted to the highly fluorescent 2',7'-dichlorofluorescein (DCF). The fluorescence intensity measured with excitation at $485 \mathrm{~nm}$ and emission at $525 \mathrm{~nm}$ directly correlates with intracellular ROS levels. Cells were incubated with the substrate for $24 \mathrm{~h}$ and fluorescence intensity in each treatment group $(n=8)$ was read with a microplate reader. Intracellular ROS level was plotted as fold-increase in fluorescence with respect to controls (untreated cells). Cell viability for each group was also measured with the resazurinmetabolic assay as described above.

\section{Flow cytometry study}

PC-3 cells were seeded into 6-well plates at a density of 50,000 cells/well and allowed to adhere for $24 \mathrm{~h}$. Cells were then treated with $10 \mu \mathrm{M}$ L-SAHA, LSAHA-Fe, L-LAQ, L-LAQ-Fe or $100 \mu \mathrm{M}$ L-Fe (a higher concentration of L-Fe was used due to its greater $I C_{50}$ as determined by the cytotoxicity study). After $72 \mathrm{~h}$ of incubation, both dead and live cells were collected, washed with PBS, and re-suspended in binding buffer $(10 \mathrm{mM}$ HEPES/ $\mathrm{NaOH}, \mathrm{pH} 7.4$, $140 \mathrm{mM} \mathrm{NaCl}, 2.5 \mathrm{mM} \mathrm{CaCl}_{2}$ ) at a concentration of $1 \times 10^{6} \mathrm{cell} / \mathrm{ml}$. Next, $1 \times 10^{5}$ cells in $100 \mu \mathrm{l}$ cell suspension were stained with both Annexin V-FITC and propidium iodide by incubation at room temperature for $15 \mathrm{~min}$. Afterwards, $400 \mu \mathrm{l}$ binding buffer was added to each sample and the cells were analyzed with a FACSCalibur flow cytometer; raw data was analyzed with FlowJo® software.

\section{Pharmacokinetic study}

All animal experiments were performed in accordance with the guidelines and protocol approved by the University of Wisconsin-Madison's Institutional Animal Care and Use Committee (IACUC). Female Sprague Dawley rats (200-220 g, 2-month-old young adults) were obtained from Charles River Laboratories (Wilmington, MA) and given food and water ad libitum for at least 5 days before use. Rats were housed in temperaturecontrolled rooms with $12 \mathrm{~h}$ light/dark cycle. For pharmacokinetic study of LAQ formulations, 15 rats were divided into 3 groups ( $\mathrm{n}=5$ per group). Rats were put under isoflurane anesthesia and then administered free LAQ, L-LAQ or L-LAQ-Fe formulations ( $5 \mathrm{mg} / \mathrm{kg} \mathrm{LAQ}$ ) in $1 \mathrm{ml}$ volume by tail vein injections. Free LAQ was dissolved in $5 \%$ dextrose prior to injection. L-LAQ and L-LAQ-Fe were prepared as described in methods and the buffer was replaced with sterile $5 \%$ dextrose by elution through a PD-10 column. At various time points, 0.15-0.2 ml whole blood samples were drawn from anesthetized rats via the tail artery into heparintreated tubes. The time points for free LAQ treated group were $0.08 \mathrm{~h}, 0.16 \mathrm{~h}, 0.5 \mathrm{~h}, 0.75 \mathrm{~h}, 1 \mathrm{~h}$ and $4 \mathrm{~h}$. The time points for L-LAQ and L-LAQ-Fe treated group were $0.08 \mathrm{~h}, 1 \mathrm{~h}, 2 \mathrm{~h}, 4 \mathrm{~h}, 12 \mathrm{~h}, 24 \mathrm{~h}$ and $48 \mathrm{~h}$. Red blood cells were separated from plasma by centrifugation at $1000 \mathrm{~g}$ for $20 \mathrm{~min}$ and stored at $80^{\circ} \mathrm{C}$ until ready for analysis by LC-MS (fee-forservice by the Analytical Instrumentation Center of the School of Pharmacy, University of WisconsinMadison). A decision of 6-7 data points per animal was made to avoid drawing more than the maximum recommended volume of blood (ca. 10\% blood volume as approved by IACUC) while allowing for each time point sampled to be analyzed by LC-MS a minimum of three times (triplicate sampling).

For LC-MS analysis of plasma samples, SAHA was used as the internal standard for the analysis of LAQ. Specifically, $50 \mu 1$ plasma samples were added to an Ostro 96-well plate (Waters, Milford, MA) and mixed with $150 \mu 1$ acetonitrile containing $1 \%$ formic acid and $50 \mathrm{ng} / \mathrm{ml}$ SAHA. Nitrogen gas was used to force the extracts through the Ostro plates to remove phospholipids and proteins. Blank rat plasma samples spiked with various concentrations of LAQ were used as calibration standards. A representative LC-MS chromatogram and a calibration curve are shown in Supplementary Information. PK variables for LAQ were calculated with PKSolver, a Microsoft Excel add-in application (23). Half-life $\left(t_{1 / 2}\right)$, area under the curve $\left(\mathrm{AUC}_{\infty}\right)$, clearance $(\mathrm{CL})$, volume of distribution $\left(\mathrm{V}_{\mathrm{d}}\right)$ and mean residence time in the circulation (MRT) of individual rats were calculated by non-compartmental analysis and reported as mean \pm SD for each group $(n=5)$.

The PK and biodistribution of iron in L-Fe and L-LAQ-Fe formulations were investigated with radioactive isotope $\mathrm{Fe}-59$. L-Fe and L-LAQ-Fe were prepared by mixing approximately $250 \mu \mathrm{Ci} \mathrm{Fe}-59$ with non-radioactive $\mathrm{FeCl}_{3}$. For the $\mathrm{PK}$ study, 10 female Sprague Dawley rats (200-220 g) were divided into two groups (5 animals per group) and injected with radioactive L-Fe or L-LAQ-Fe by tail vein; each injection was characterized by $6-7 \mu \mathrm{Ci} \mathrm{Fe}-$ 
59 activity. At time point $0.08 \mathrm{~h}, 1 \mathrm{~h}, 2 \mathrm{~h}, 4 \mathrm{~h}, 12 \mathrm{~h}$, $24 \mathrm{~h}$ and $48 \mathrm{~h}, 0.15-0.2 \mathrm{ml}$ whole blood samples (to be consistent with the first study) were drawn from tail artery into heparin-treated tubes and plasma was separated from the blood cells by centrifugation at $1000 \mathrm{~g}$ for $20 \mathrm{~min}$. For the biodistribution study, rats were euthanized by carbon dioxide inhalation at the end of the PK study ( $48 \mathrm{~h}$ ), and spleen, kidneys, liver, lung, heart, muscle and right femur were collected and weighed. The radioactivity of $\mathrm{Fe}-59$ present in all tissues (including plasma and blood cells) was measured with a 2480 WIZARD2 Automatic Gamma Counter. Results are expressed as the percentage of injected dose per gram of tissue $(\% \mathrm{ID} / \mathrm{g})$ and also as percentage of injected dose (\%ID) for the whole organ. The \%ID in plasma and blood cells were calculated assuming a hematocrit of $40 \%$ and assuming whole blood makes up $6.5 \%$ of total rat body weight. Because of the different quantitation approaches utilized for detecting the drug (units of concentrations) and Fe-59 (units of radioactivity) in the two PK assays, only the $t_{1 / 2}$ of Fe-59 in L-Fe and L-LAQ-Fe in the plasma was calculated via non-compartmental analysis with PKSolver.

\section{STATISTICAL ANALYSIS}

Statistical analysis was performed with GraphPad Prism 5.0 software. Statistical significance between two groups was tested with Student's t-test. Differences among three or more groups were analyzed by one-way analysis of variance (ANOVA) and Turkey's multiple comparison tests. Two-tailed $p$ value less than 0.05 was considered statistically significant.

\section{RESULTS}

\section{Solubility}

We tested the solubility of both SAHA and LAQ under various $\mathrm{pH}$ conditions at $25^{\circ} \mathrm{C}$ (Table 1). SAHA did not solubilize well in $\mathrm{ddH}_{2} \mathrm{O}(\mathrm{pH}$ 6) or acidic $\mathrm{pH}(\mathrm{pH} 2)$, with only $0.16 \mathrm{mg} / \mathrm{ml}$ drug dissolved under these conditions after $48 \mathrm{~h}$ of equilibration. In contrast, SAHA was most soluble at $4.8 \mathrm{mg} / \mathrm{ml}$ when dissolved in a basic $\mathrm{pH}$ solution $(\mathrm{pH}$ 12); in the presence of excess $\mathrm{FeCl}_{3}$, the solubility of SAHA (as a complex) increased from $0.16 \mathrm{mg} / \mathrm{ml}$ to $2.6 \mathrm{mg} / \mathrm{ml}$, resulting in a 16-fold increase in solubility. This was also readily observed from the appearance of a dark purple color upon addition of SAHA to the (initially yellow) $\mathrm{FeCl}_{3}$ solution, indicative of SAHA-Fe complex formation. LAQ displayed very poor solubility in $\mathrm{ddH}_{2} \mathrm{O}(\mathrm{pH}$ 6) of only $0.008 \mathrm{mg} / \mathrm{ml}$, but became much more soluble in acidic solution ( $\mathrm{pH} 2$ ) at $4.1 \mathrm{mg} / \mathrm{ml}$ due to protonation of its tertiary amine. Similar to SAHA, LAQ was also quite soluble in alkaline solution $(\mathrm{pH}$ 12 ), with a solubility of $3.4 \mathrm{mg} / \mathrm{ml}$. In the presence of excess $\mathrm{FeCl}_{3}$, the solubility of LAQ dramatically increased from $0.008 \mathrm{mg} / \mathrm{ml}\left(\mathrm{pH} 6 \mathrm{ddH}_{2} \mathrm{O}\right)$ to 4.2 $\mathrm{mg} / \mathrm{ml}$, a dramatic 525-fold increase in solubility.

\section{HDACi-Fe stoichiometry and binding constants} The complexes of SAHA-Fe and LAQ-Fe (Fig. 1) display a characteristic absorption peak at about 500 $\mathrm{nm}$ which can be used to quantify the concentration of HDACi-Fe complexes (Fig. 2a, 2b). By using the continuous variation method (18), we were able to determine the reaction stoichiometry for complex formation between SAHA/LAQ and Fe(III) (Fig. 2c, 2d). $\mathrm{HDACi}$ and $\mathrm{FeCl}_{3}$ were mixed at different molar ratios while keeping the total mole concentration of the solution constant. The absorption at $500 \mathrm{~nm}$ was plotted with respect to HDACi mole percentage, and tangents from each side of the curve were extended to find the point of intersection. For both SAHA and LAQ, the points of intersection occurred at about $50 \%$ SAHA/LAQ, indicative of a 1:1 molar ratio complexation between drug and $\mathrm{Fe}(\mathrm{III})$. The binding constants for SAHA-Fe and LAQ-Fe were calculated by generating a linear best-fit line (see method description) through a graph of $1 /$ (absorbance) with respect to $1 /(\mathrm{Fe}$ concentration), Fig. 2e, 2f. SAHA$\mathrm{Fe}$ was characterized by a binding constant of $2.0 \times 10^{4} \mathrm{M}^{-1}$ and the binding constant for LAQ-Fe was found to be $2.2 \times 10^{4} \mathrm{M}^{-1}$.

Table 1 Aqueous solubility of SAHA and LAQ in different solutions at $25^{\circ} \mathrm{C}$ (unit: $\mathrm{mg} / \mathrm{ml}$ ).

\begin{tabular}{lllll}
\hline HDACi & $\mathrm{pH} 2$ & $\mathrm{pH} 6$ & $\mathrm{pH} 12$ & $\mathrm{FeCl}_{3} *$ \\
\hline SAHA & $0.16 \pm 0.02$ & $0.16 \pm 0.03$ & $4.8 \pm 0.4$ & $2.6 \pm 0.3$ \\
LAQ & $4.1 \pm 0.2$ & $0.008 \pm 0.001$ & $3.4 \pm 0.1$ & $4.2 \pm 0.3$ \\
\hline
\end{tabular}

* This solution was acidified with $10 \mathrm{mM} \mathrm{HCl}$ to prevent $\mathrm{Fe}(\mathrm{III})$ from precipitating, ca. pH 2. 
Table 2 Physicochemical characteristics of liposome formulations.

\begin{tabular}{lcccc}
\hline Formulation & Size. $\mathrm{d}(\mathrm{nm})$ & PDI & Zeta-potential $(\mathrm{mV})$ & EE \\
\hline L-SAHA-Fe & $151 \pm 2$ & $0.074 \pm 0.015$ & $-9.4 \pm 0.6$ & $35 \pm 5 \%$ \\
L-LAQ-Fe & $160 \pm 2$ & $0.069 \pm 0.018$ & $-9.9 \pm 0.6$ & $29 \pm 4 \%$ \\
L-SAHA & $126 \pm 1$ & $0.057 \pm 0.008$ & $-14.4 \pm 0.4$ & $20 \pm 1 \%$ \\
L-LAO & $161 \pm 2$ & $0.065 \pm 0.010$ & $-17.5 \pm 1.3$ & $19 \pm 1 \%$ \\
L-Fe & $171 \pm 2$ & $0.046 \pm 0.012$ & $-10.4 \pm 0.2$ & $19 \pm 2 \%$ \\
\hline
\end{tabular}<smiles>O=C(CCCCCCC(=O)Nc1ccccc1)Nc1ccccc1</smiles>
suberoylanilide hydroxamic acid (SAHA)<smiles>O=C(/C=C/c1ccc(CN(CCO)CCC2=c3ccccc3=NC2)cc1)NO</smiles>

LAQ824

Figure. 1 Chemical structure of SAHA and LAQ, and their hypothesized structures upon complexation with Fe at a stoichiometric ratio of 1:1.

\section{Physicochemical characterization of liposomes} The physicochemical properties of L-SAHA-Fe, LLAQ-Fe, L-SAHA, L-LAQ, and L-Fe are reported in Table 2. All of the liposome formulations had an average diameter of ca. $150 \mathrm{~nm}$ with a narrow size distribution, characterized by a PDI $<0.1$. L-SAHA resulted in the smallest nanoparticle with a diameter of $126 \mathrm{~nm}$, whereas L-Fe resulted in the largest nanoparticles averaging ca. $171 \mathrm{~nm}$. Zeta-potentials of the formulations ranged from $-9.4 \mathrm{mV}$ to -17.5 $\mathrm{mV}$ and were all slightly negative due to the presence of DPPE-PEG 2000 on the liposomal surface (DPPE has a anionic head group). Liposomal HDACi-Fe complexes and L-Fe were characterized by a zetapotential of about $-10 \mathrm{mV}$; L-SAHA and L-LAQ were characterized by zeta potentials of $-14.4 \mathrm{mV}$ and $-17.5 \mathrm{mV}$ respectively. The liposome formulations were stable, with particle sizes and drug concentrations practically not changing after storage at $4^{\circ} \mathrm{C}$ for up to one month (data not shown). The EE of HDACi-Fe complexes were notably higher (29\%$35 \%$ ) than for either HDACi drug alone (19\%-20\%).

\section{In vitro drug release}

The in vitro release kinetics for all formulations was studied at $37^{\circ} \mathrm{C}$ by the dialysis method. After $3 \mathrm{~h}$ of dialysis, free SAHA completely released from LSAHA (Fig. 3a). On the other hand, ca. $50 \%$ of SAHA released from L-SAHA-Fe in ca. $3 \mathrm{~h}$, and $90 \%$ released after ca. $9 \mathrm{~h}$. As expected, there was very little release of Fe from L-SAHA-Fe, with only ca. $20 \% \mathrm{Fe}$ released after $24 \mathrm{~h}$; this confirms that SAHA is indeed not released from liposomes in complex form but rather as the free drug. We found that LLAQ released 50\% LAQ after ca. $6 \mathrm{~h}$ and $90 \%$ after 24 h (Fig. 3b), whereas L-LAQ-Fe displayed a dramatically more sustained release profile, with time to $50 \%$ release of ca. 2 days and $90 \%$ release in ca. 5.5 days. We found that only $60 \% \mathrm{Fe}$ had been released from L-LAQ-Fe by day 7 (end of experiment). Fe release from L-Fe was very slow and similar to Fe release kinetics observed in L-SAHA$\mathrm{Fe}$ and L-LAQ-Fe formulations (data not shown).

\section{Cytotoxicity}

Dose response of the free drugs and liposome formulations were tested on cultured PC-3 human prostate cancer cells via a metabolism-based assay (Fig. 4). $I C_{50}$ values are summarized in Table 3. The $I C_{50}$ of SAHA was found to be $2.8 \mu \mathrm{M}$, consistent with the NCI Cancer Screen reported value $\left(G I_{50}=\right.$ $2.0 \mu \mathrm{M}$ in PC-3 cells) and the $I C_{50}$ of L-SAHA was 
found to be $1.0 \mu \mathrm{M}$. Free SAHA-Fe complex had an $I C_{50}$ of $0.6 \mu \mathrm{M}$ and L-SAHA-Fe complex was characterized by an $I C_{50}$ of $1.2 \mu \mathrm{M}$. LAQ and its related formulations were generally more potent than SAHA, with $I C_{50}$ values in the nanomolar range. The $I C_{50}$ of LAQ was found to be $71 \mathrm{nM}$ and $108 \mathrm{nM}$ for L-LAQ. Free LAQ-Fe had an $I C_{50}$ of $5 \mathrm{nM}$ and LLAQ-Fe complex was characterized by an $I C_{50}$ of 18 nM.

Based on overlaps of the dose response curves for both SAHA (Fig. 4a) and LAQ (Fig. 4b), Fe complexation and encapsulation into liposomes did not drastically alter the overall potency of the drugs, with $I C_{50}$ s close in magnitude to those of the original drugs. To investigate further the role that Fe may have on the cytotoxicity, the dose response of free $\mathrm{FeCl}_{3}$ and L-Fe was also investigated (Fig. 4c). We found that it required a very high concentration of free $\mathrm{FeCl}_{3}\left(I C_{50}=4.8 \mathrm{mM}\right)$ in the medium before growth of cells became $50 \%$ inhibited. In sharp contrast, the $I C_{50}$ of L-Fe was found to be $38 \mu \mathrm{M}$, resulting in a formulation 100 times more potent than free $\mathrm{FeCl}_{3}$. We noticed that the L-Fe dose response curve dropped very steeply at a critical concentration range of 20 to $40 \mu \mathrm{M} \mathrm{L}-\mathrm{Fe}$, indicative of a critical Fe threshold value in cells before dramatic inhibition of cellular metabolic processes; at concentrations below this critical value, $>90 \%$ cells survived.

\section{Cell death mechanism}

To investigate further whether the combination of HDACi and $\mathrm{Fe}(\mathrm{III})$ could increase ROS production in cells, we treated PC-3 cells with L-Fe, L-HDACi and L-HDACi-Fe at both 1 and $10 \mu \mathrm{M}$ concentrations. As shown in Fig. 5a, when cells were treated with $1 \mu \mathrm{M}$ L-SAHA-Fe, intracellular ROS increased 1.7-fold after $24 \mathrm{~h}$, but was not statistically significant from levels detected in cells treated with $1 \mu \mathrm{M}$ L-Fe (1.8-fold ROS production) or $1 \mu \mathrm{M} \mathrm{L}$ SAHA (1.6-fold ROS production). When cells were treated with $10 \mu \mathrm{M}$ L-SAHA-Fe, intracellular ROS increased 2.1-fold which was again not statistically different from cells treated with $10 \mu \mathrm{M}$ L-Fe (2.0fold ROS production). In contrast, cells treated with $10 \mu \mathrm{M}$ L-SAHA significantly generated 4.1-fold more ROS, $\mathrm{p}<0.01$. When cell viability was simultaneously measured (Fig. 5c), it was apparent that neither $1 \mu \mathrm{M}$ nor $10 \mu \mathrm{M}$ L-Fe affected cell viability, whereas L-SAHA and L-SAHA-Fe were able to reduce cell viability significantly at both concentrations. It is worth noting that although 10 $\mu \mathrm{M} \quad$ L-SAHA-Fe treatments only increased intracellular ROS 2.1-fold (in contrast to 4.1-fold increase by $10 \mu \mathrm{M}$ L-SAHA), both formulations resulted in ca. $80 \%$ decrease in cell viability, meaning that cell viability did not appear to correlate directly with ROS production.

To investigate whether apoptosis is the major mechanism of cell death, PC-3 cells were treated with different formulations of L-SAHA, L-SAHA$\mathrm{Fe}, \mathrm{L}-\mathrm{LAQ}$ and LAQ-Fe at $10 \mu \mathrm{M}$; L-Fe was added to cells at $100 \mu \mathrm{M}$ (this concentration $>$ the critical threshold value). After $72 \mathrm{~h}$ of incubation, both live and dead cells were collected and stained with Annexin V-FITC and PI, and analyzed by flow cytometry. In apoptotic cells, the membrane phospholipid phosphatidylserine (PS) is translocated from the inner to the outer leaflet of the plasma membrane allowing Annexin $\mathrm{V}$ protein to specifically bind exposed PS. Viable cells with intact membranes should exclude PI whereas the membranes of dead and damaged cells should be more permeable to PI. Therefore, viable cells should be both Annexin V-FITC and PI negative; cells in the early apoptosis stage should be Annexin V-FITC positive and PI negative; cells that are in the late apoptotic or dead stage should be Annexin V-FITC and PI positive; necrotic cells should be Annexin VFITC negative and PI positive. As shown, 95\% of untreated cells were viable (Fig. 6a); most cells treated with L-Fe (Fig. 6b), L-SAHA (Fig. 6c), LSAHA-Fe (Fig. 6d), L-LAQ (Fig. 6e) or L-LAQ-Fe (Fig. 6f) were mainly characterized by apoptosis at various stages, with many cells either undergoing early apoptosis or late apoptosis, or already dead. No evidence of necrosis was observed for all the treatment groups.

\section{Pharmacokinetics}

The PK parameters of LAQ formulations (Fig. 7), Fe and its biodistribution (Fig. 8), were investigated through the use of LC-MS and radioactive Fe-59. The PK variables of LAQ were summarized in Table 4. Following I.V. bolus injection into rats, free LAQ was quickly cleared from the blood with $t_{1 / 2}$ of 0.79 $\mathrm{h}, \mathrm{L}-\mathrm{LAQ}$ was characterized by a slightly longer $t_{1 / 2}$ of $1.89 \mathrm{~h}$ compared to free LAQ $(\mathrm{p}<0.05)$ and LLAQ-Fe had the longest $t_{1 / 2}$ at $12.11 \mathrm{~h}(\mathrm{p}<0.05$ compared with either free LAQ or L-LAQ). The $\mathrm{AUC}_{\infty}$ also significantly increased for all the liposome formulations compared to free LAQ, with 36-fold increase for L-LAQ $(\mathrm{p}<0.05)$ and 211-fold increase for L-LAQ-Fe $(p<0.05$ compared with either free LAQ or L-LAQ). The mean residence 
time (MRT) of L-LAQ-Fe in the rat was much longer at $16.9 \mathrm{~h}(\mathrm{p}<0.05$ compared with either free LAQ or L-LAQ), in contrast to the $1.71 \mathrm{~h}$ for L-LAQ ( $<$ 0.05 ) and $0.35 \mathrm{~h}$ for free LAQ. The rate of drug clearance (CL) was much more rapid for LAQ $(10027 \mathrm{ml} / \mathrm{h} \cdot \mathrm{kg})$, followed by L-LAQ (113.2 $\mathrm{ml} / \mathrm{h} \cdot \mathrm{kg}, \mathrm{p}<0.05)$, and finally L-LAQ-Fe $(19.2$

(a)

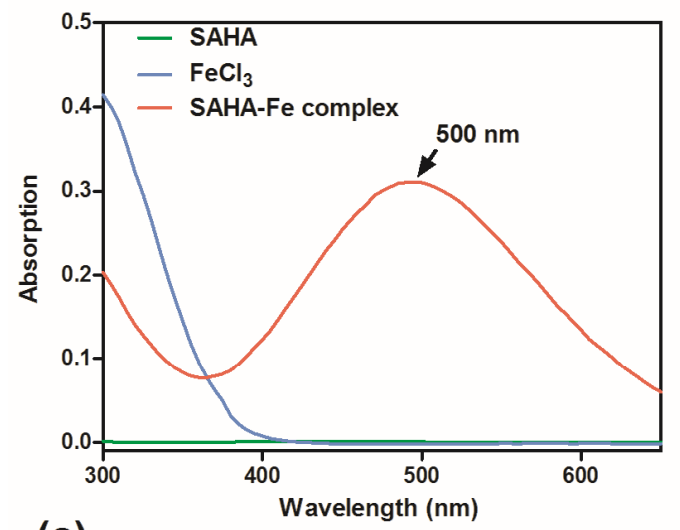

(c)

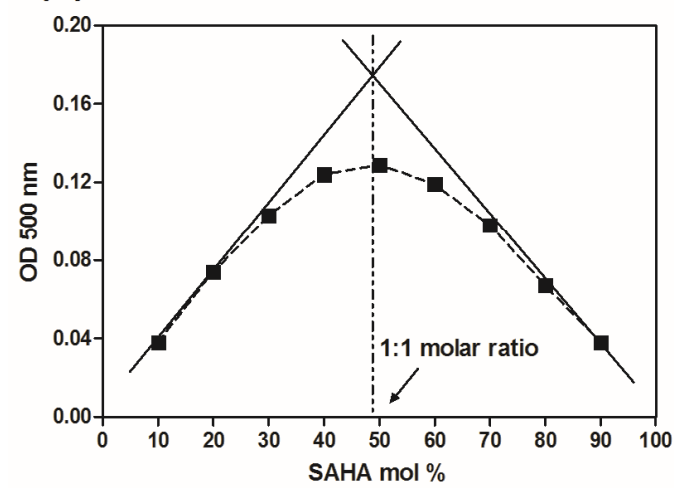

(e)

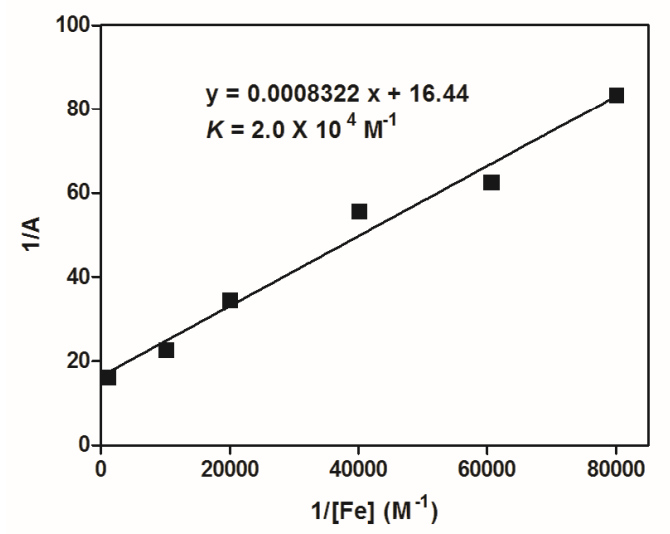

$\mathrm{ml} / \mathrm{h} \cdot \mathrm{kg}, \mathrm{p}<0.05$ compared with either free LAQ or L-LAQ). The volume of distribution $\left(\mathrm{V}_{\mathrm{d}}\right)$ for free LAQ was much larger $(11310 \mathrm{ml} / \mathrm{kg})$ than for LLAQ $(307 \mathrm{ml} / \mathrm{kg}, \mathrm{p}<0.05)$ and L-LAQ-Fe (335.6 $\mathrm{ml} / \mathrm{kg}, \mathrm{p}<0.05)$; there was no statistical difference between the $\mathrm{V}_{\mathrm{d}}$ of L-LAQ and L-LAQ-Fe.

(b)

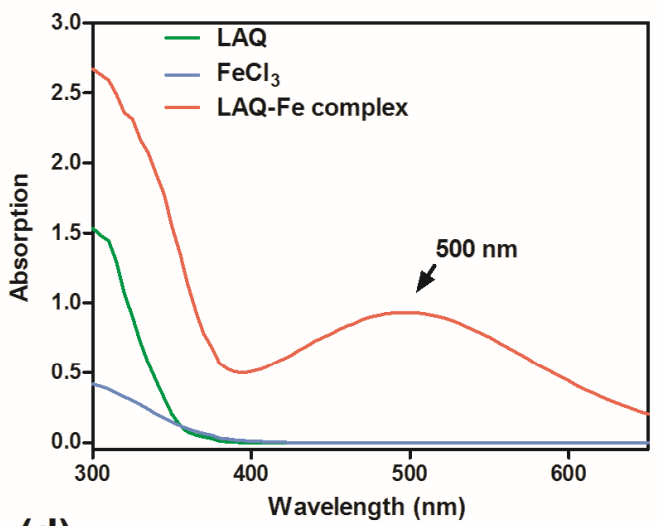

(d)

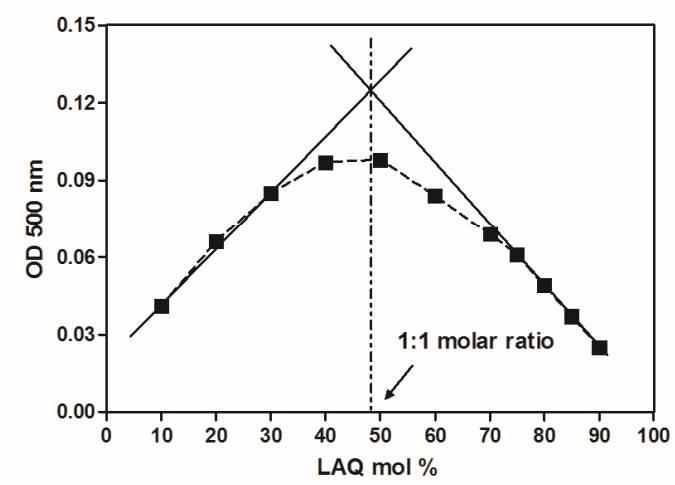

(f)

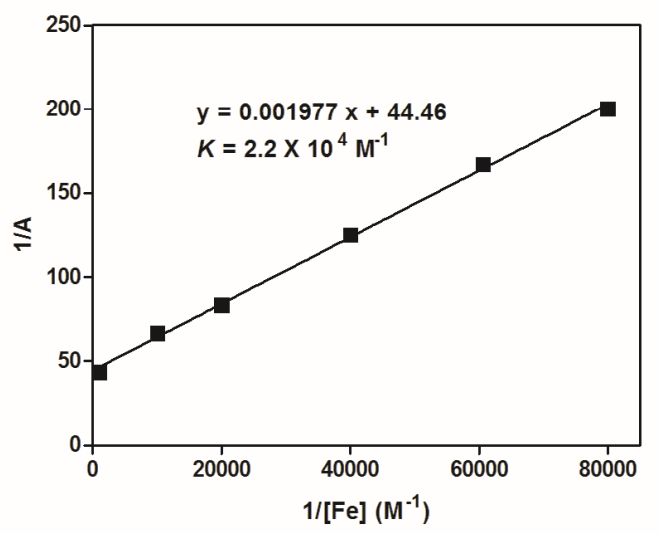

Figure. 2 Characterization of HDACi-Fe complexes. (a) UV-Vis spectrum showing the characteristic absorption peak at ca. $500 \mathrm{~nm}$ for SAHA-Fe complex. (b) UV-Vis spectrum showing the characteristic absorption peak at ca. $500 \mathrm{~nm}$ for LAQ-Fe complex. (c) SAHA complexes with Fe at a 1:1 molar ratio. (d) LAQ complexes with Fe at a 1:1 molar ratio. (e) The binding constant of SAHA-Fe complex was found to be $2.0 \times 10^{4} \mathrm{M}^{-1}$. (f) The binding constant of LAQ-Fe complex was found to be $2.2 \times 10^{4} \mathrm{M}^{-1}$. 


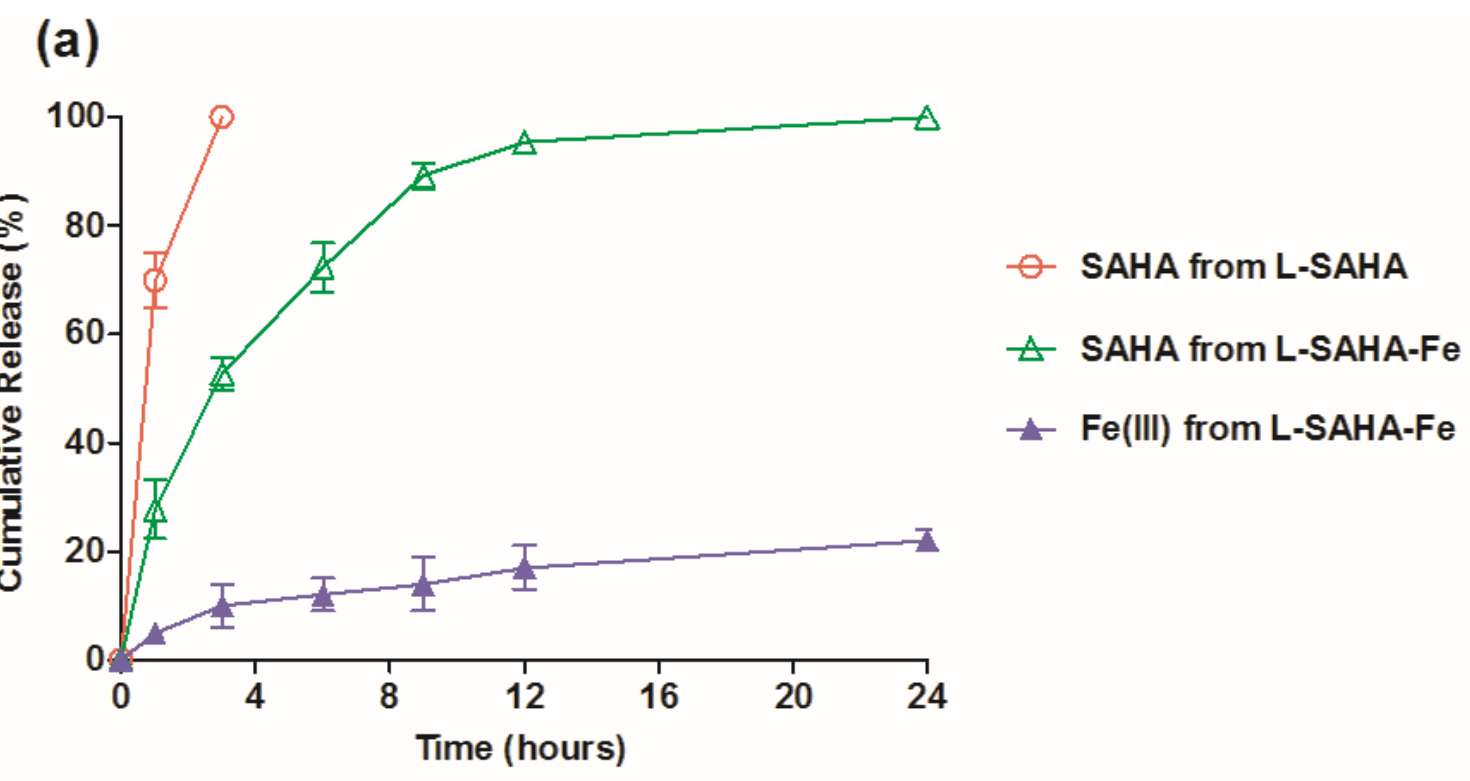

(b)

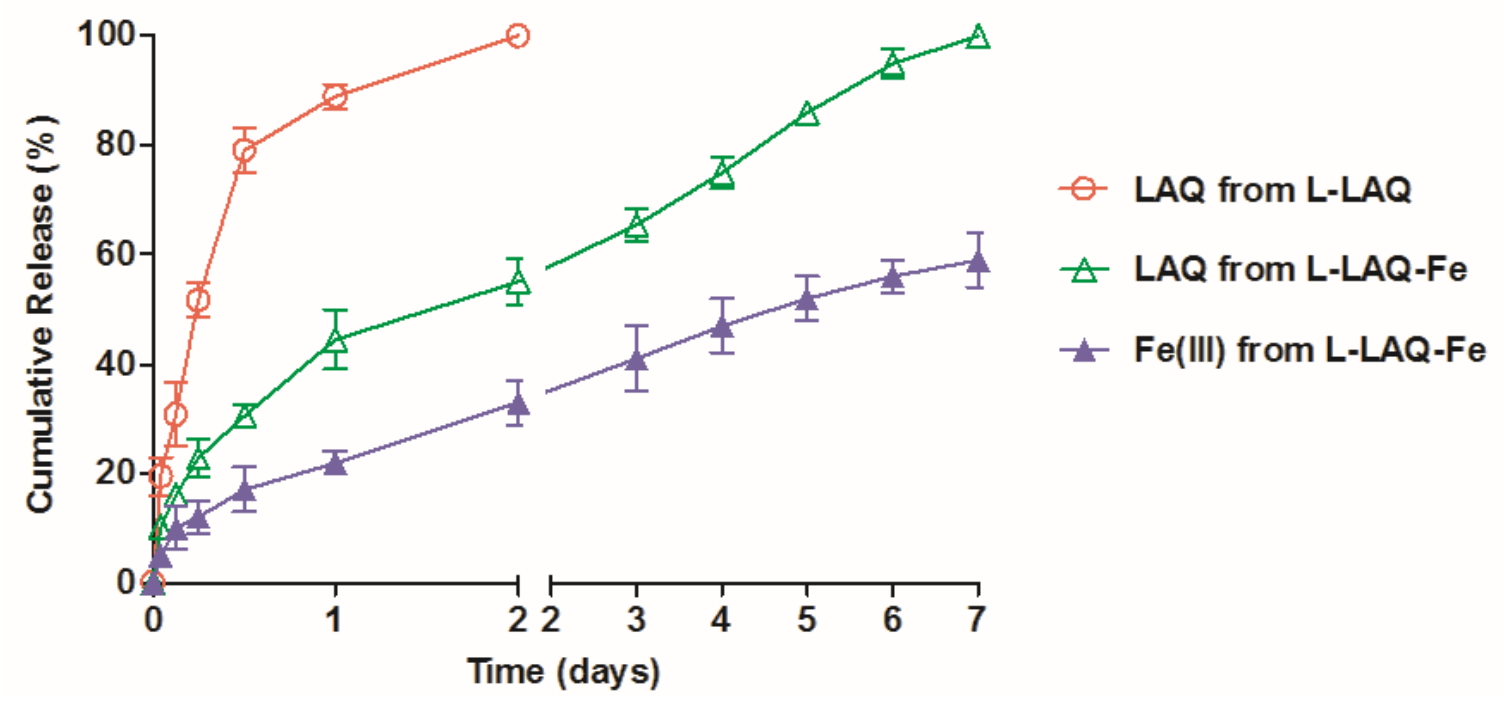

Figure. 3 In vitro release study for SAHA (a) and LAQ (b) in $\mathrm{pH} 7.4$ buffer at $37^{\circ} \mathrm{C}(\mathrm{n}=3$, mean $\pm \mathrm{SD})$.

Table $3 I C_{50}$ values of free $\mathrm{HDACi}, \mathrm{FeCl}_{3}$ and their liposomal formulations.

\begin{tabular}{lll}
\hline Formulation & Free form & Liposomal formulation \\
\hline SAHA & $2.8 \pm 0.4 \mu \mathrm{M}$ & $1.0 \pm 0.2 \mu \mathrm{M}$ \\
SAHA-Fe & $0.6 \pm 0.2 \mu \mathrm{M}$ & $1.2 \pm 0.3 \mu \mathrm{M}$ \\
LAQ & $71 \pm 5 \mathrm{nM}$ & $108 \pm 20 \mathrm{nM}$ \\
LAQ-Fe & $5 \pm 2 \mathrm{nM}$ & $18 \pm 5 \mathrm{nM}$ \\
$\mathrm{FeCl}_{3}$ & $4.8 \pm 0.6 \mathrm{mM}$ & $38 \pm 11 \mu \mathrm{M}$ \\
\hline
\end{tabular}


(a)

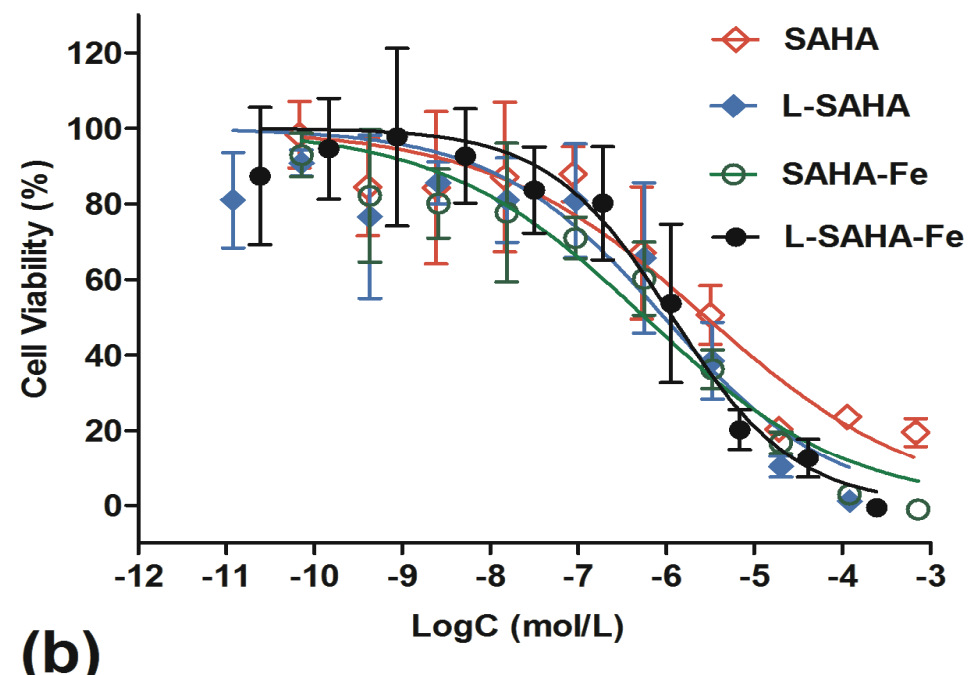

(b)

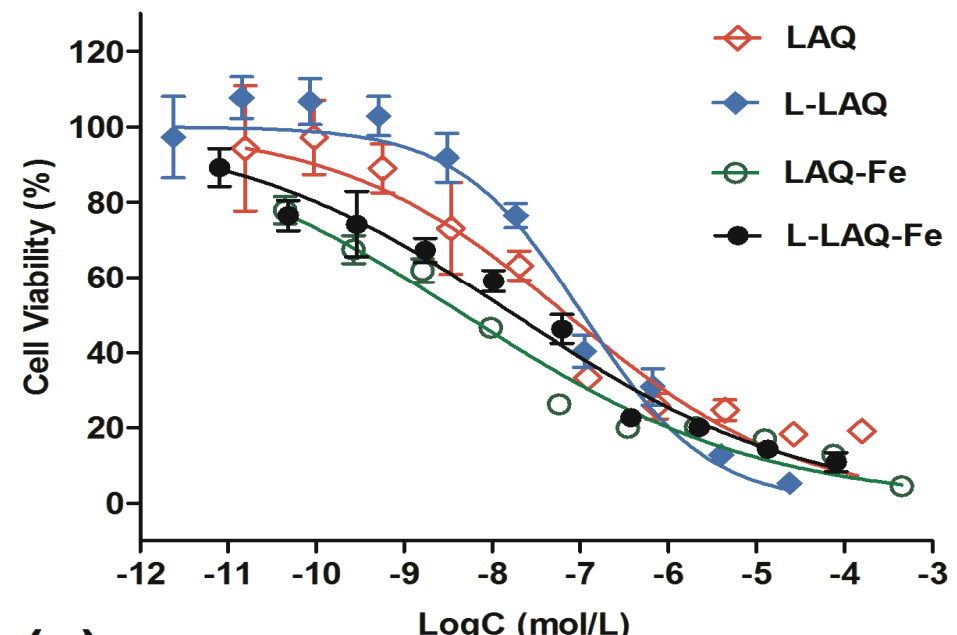

(c)

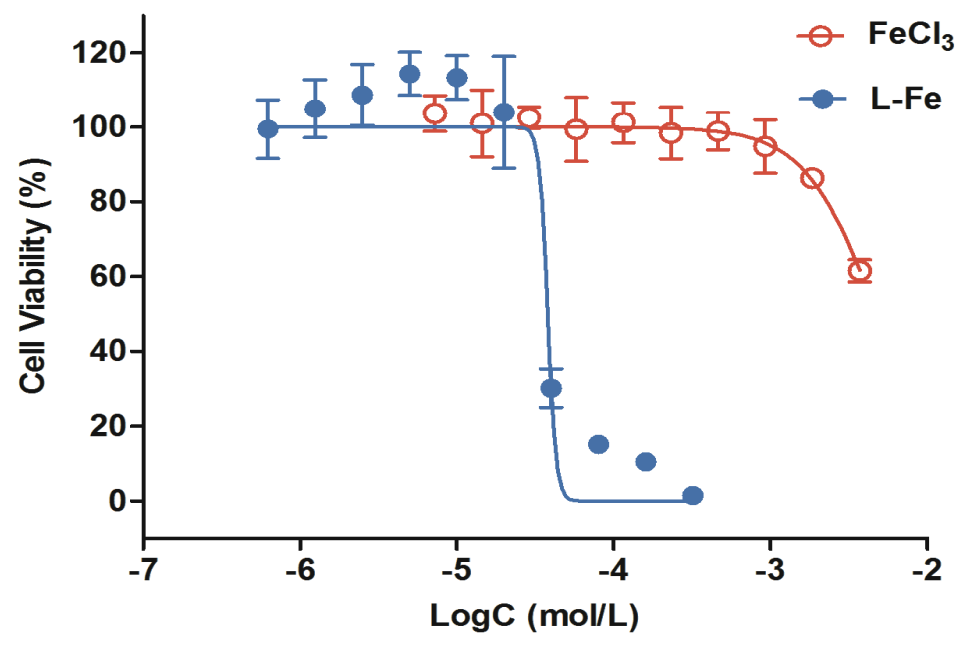

Figure. 4 Dose response curves for SAHA, L-SAHA, SAHA-Fe, L-SAHA-Fe (a), LAQ, L-LAQ, LAQ-Fe, L-LAQ-Fe (b), $\mathrm{FeCl}_{3}$ and $\mathrm{L}-\mathrm{Fe}(\mathbf{c})$ in PC-3 human prostate cancer cells $(\mathrm{n}=4$, mean $\pm \mathrm{SD}) . I C_{50}$ values were calculated by fitting the data to a nonlinear logarithm curve using GraphPad Prism 5.0 software and are summarized in Table 3. 
(a)

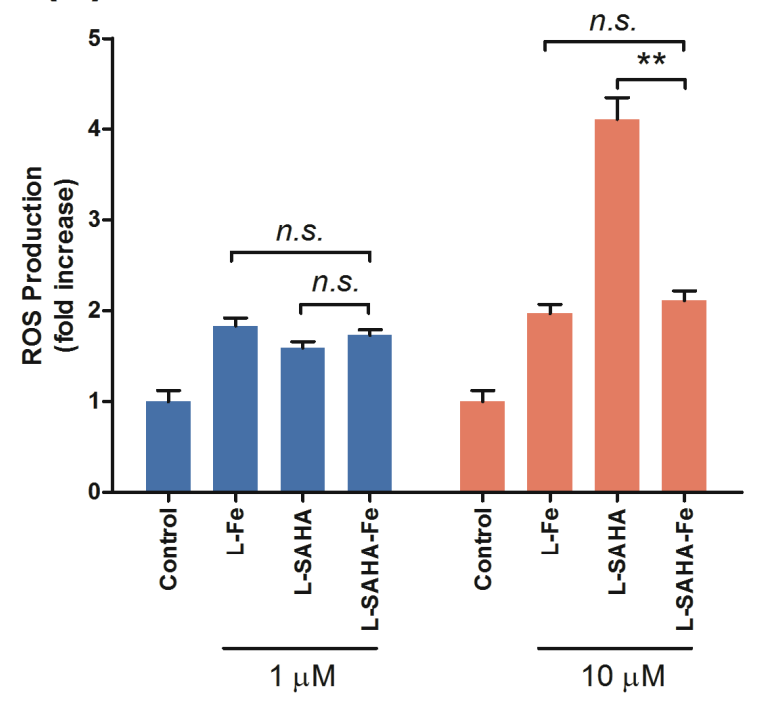

(c)

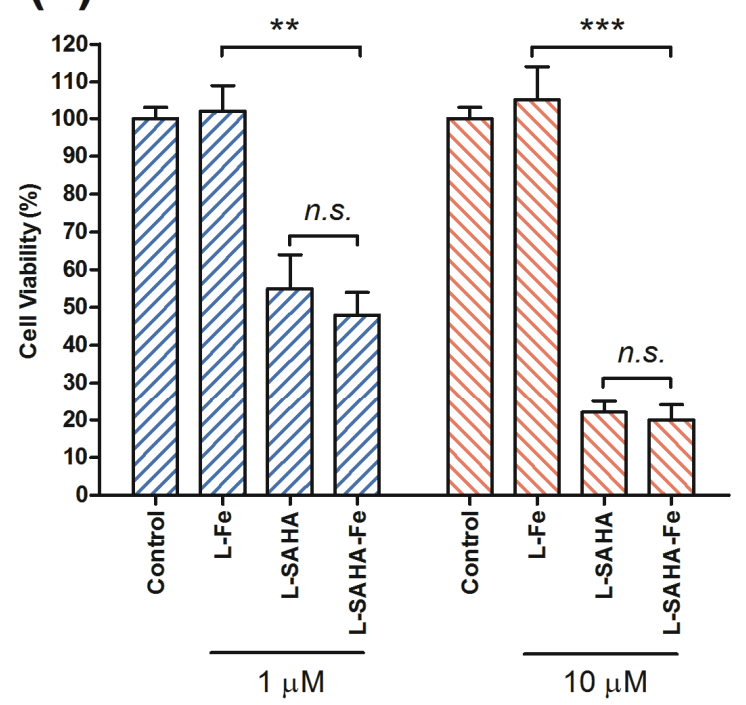

(b)

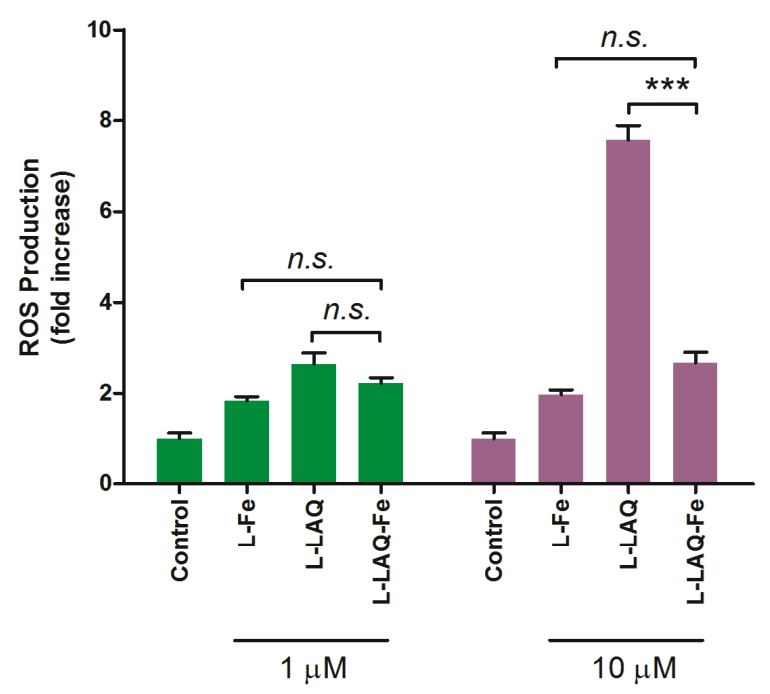

(d)

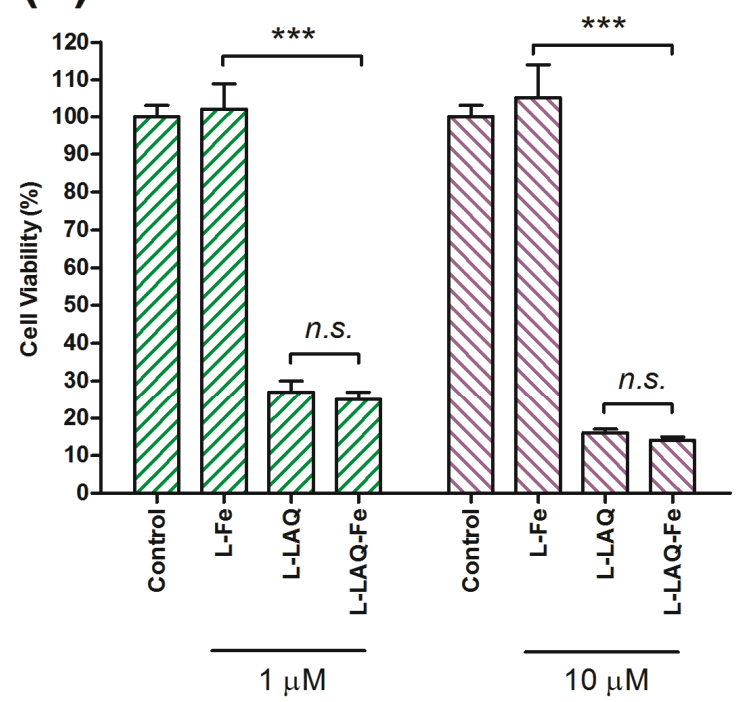

Figure. 5 Oxidative stress and cell viability studies in PC-3 cells ( $\mathrm{n}=8$, mean $\pm \mathrm{SD}$ ). Cells were stained with $\mathrm{H}_{2} \mathrm{DCFDA}$, and then treated with L-Fe, L-SAHA, and L-SAHA-Fe at $1 \mu \mathrm{M}$ and $10 \mu \mathrm{M}$ concentrations. At $24 \mathrm{~h}$, the fluorescence intensity was plotted as the fold-increase with respect to controls (a); corresponding cell viability at these concentrations was measured with the resazurin-metabolic assay (c). Similar experiments were conducted for L-LAQ and L-LAQ-Fe (b), (d); "n.s." stands for not significant; $* * \mathrm{p}<0.01, * * * \mathrm{p}<0.001$.

Table 4 Pharmacokinetic variables of different LAQ formulations in rats.

\begin{tabular}{llll}
\hline & Free LAQ & L-LAQ & L-LAQ-Fe \\
\hline$t_{1 / 2}(\mathrm{~h})$ & $0.79 \pm 0.11$ & $1.89 \pm 0.11 *$ & $12.11 \pm 3.96 * \dagger \dagger \dagger$ \\
$\mathrm{AUC}_{\infty}(\mu \mathrm{g} \cdot \mathrm{h} / \mathrm{ml})$ & $0.50 \pm 0.05$ & $17.9 \pm 2.5 *$ & $105.7 \pm 13.9 * \dagger$ \\
$\mathrm{CL}(\mathrm{ml} / \mathrm{h} \cdot \mathrm{kg})$ & $10027 \pm 1090$ & $113.2 \pm 14.5 *$ & $19.2 \pm 2.4 * \dagger$ \\
$\mathrm{V}_{\mathrm{d}}(\mathrm{ml} / \mathrm{kg})$ & $11310 \pm 1264$ & $307.3 \pm 36.5 *$ & $335.6 \pm 121.9 *$ \\
$\mathrm{MRT}(\mathrm{h})$ & $0.35 \pm 0.08$ & $1.71 \pm 0.20 *$ & $16.9 \pm 6.0 * \dagger$ \\
\hline
\end{tabular}

* Difference with free LAQ is statistically significant $(\mathrm{p}<0.05)$.

$\dagger$ Difference with L-LAQ is statistically significant $(\mathrm{p}<0.05)$. 

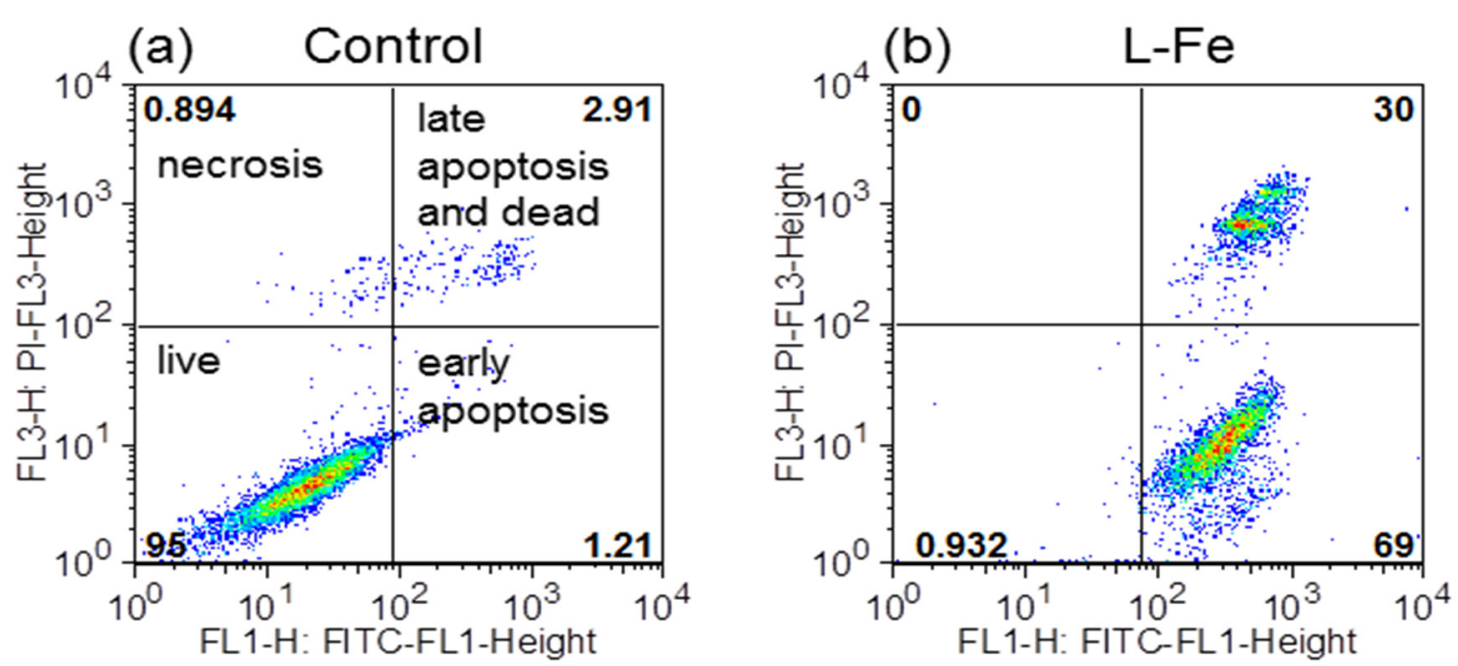

(c) L-SAHA
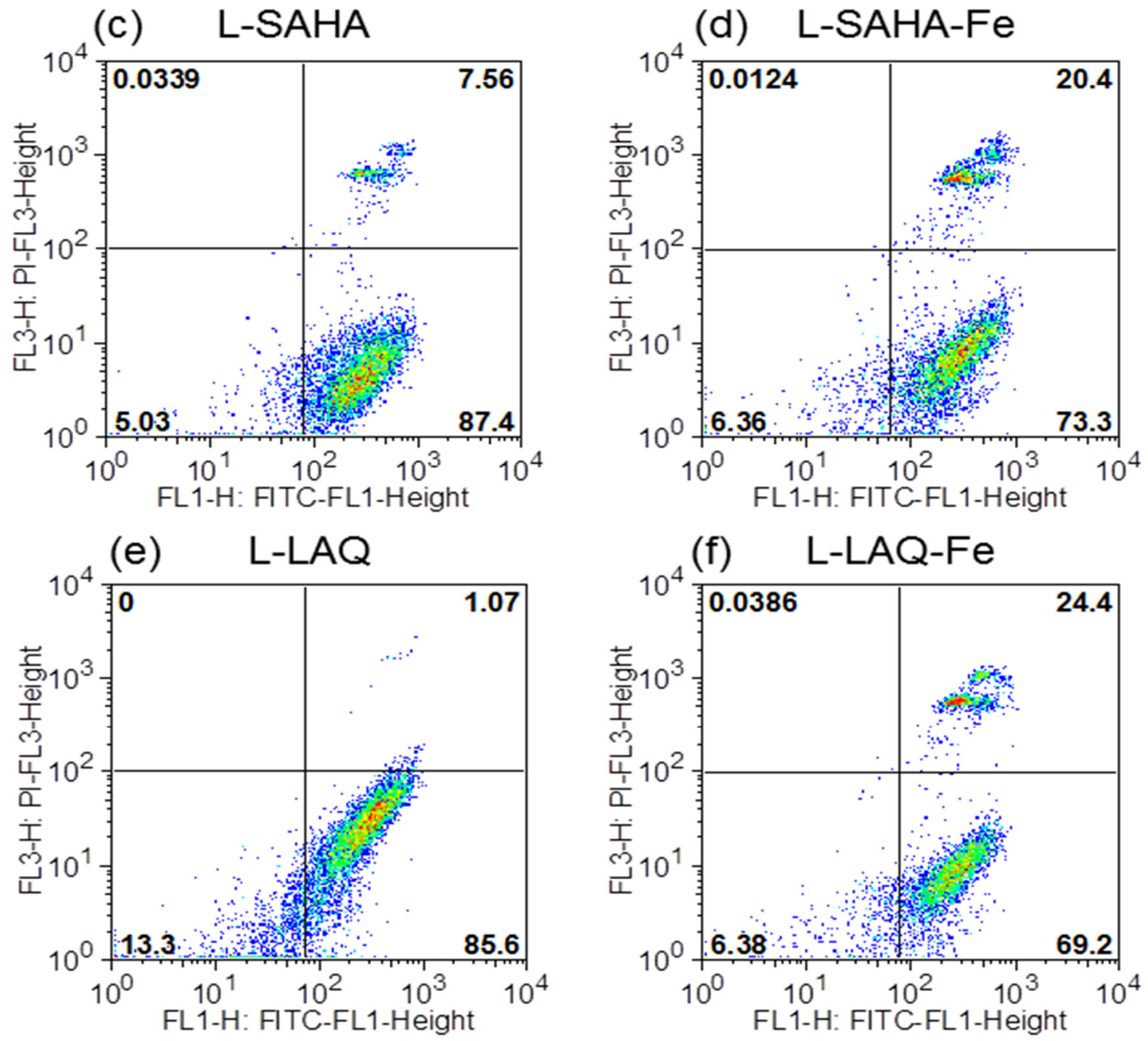

Figure. 6 Flow cytometry study. PC-3 cells were untreated (a), or treated with $100 \mu \mathrm{M} \mathrm{L-Fe} \mathrm{(b)} 10 \mu \mathrm{M}$ L-SAHA (c), $10 \mu \mathrm{M}$ L-SAHA-Fe (d), $10 \mu \mathrm{M}$ L-LAQ (e), or $10 \mu \mathrm{M}$ L-LAQ-Fe (f). After incubation for $72 \mathrm{~h}$, both live and dead cells were collected. Untreated cells were primarily Annexin V-FITC and PI negative, indicating that they were viable and not undergoing apoptosis. Cells treated with L-SAHA, L-SAHA-Fe, L-LAQ, L-LAQ-Fe and L-Fe were all found to be undergoing early apoptosis (Annexin V-FITC positive and PI negative) or late apoptosis (Annexin V-FITC and PI positive). No necrosis was observed for any of the treatments (Annexin V-FITC negative and PI positive). 


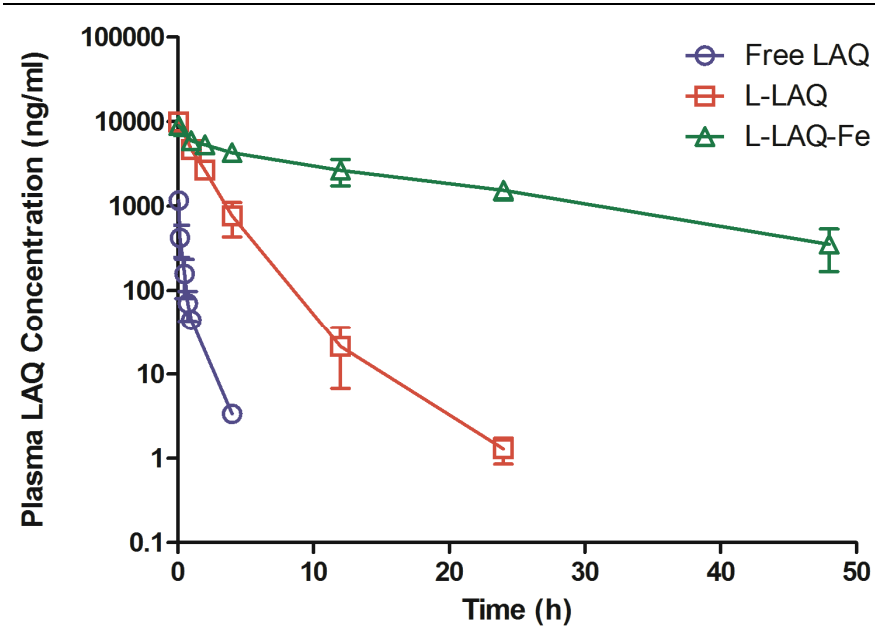

Figure. 7 Plasma LAQ concentration $(\mathrm{ng} / \mathrm{ml})$ for free LAQ, L-LAQ and L-LAQ-Fe following I.V. bolus administration $(5 \mathrm{mg} / \mathrm{kg})$ to rats $(\mathrm{n}=5$, mean $\pm \mathrm{SD})$. PK parameters were calculated with PKSolver based on noncompartmental analysis and summarized in Table 4.

The fate of $\mathrm{Fe}$ in the L-Fe and L-LAQ-Fe formulations was tracked by measuring the radioactivity of Fe-59 after I.V. injection into rats. The plasma $t_{1 / 2}$ of Fe-59 in L-LAQ-Fe was determined to be $11.83 \pm 1.28 \mathrm{~h}$ and L-Fe had a $t_{1 / 2}$ of $9.85 \pm 2.23 \mathrm{~h}$ (Fig. 8a); the difference is not statistically significant $(\mathrm{p}>0.05)$. Evidence of Fe release from liposomes was indirectly monitored by measuring Fe-59 activity in erythrocytes which slowly increased over $48 \mathrm{~h}$ due to Fe recycling by the body and/or incorporation into hemoglobin of erythrocytes. At the end of the PK experiment, organs collected were measured with a gamma counter. Spleen, blood cells (mainly erythrocytes) and liver were identified as the major organs of Fe59 distribution; to a lower degree, Fe-59 activity was also found in kidney, bone (most likely bone marrow), lung, heart and plasma; muscle displayed the lowest accumulation of Fe-59 (Fig. 8b, 8c). There was more Fe-59 activity found in the spleen of L-LAQ-Fe animals compared to L-Fe animals ( $\mathrm{p}<$ 0.05 ), but other organs displayed similar levels of radioactivity between the two groups.

\section{DISCUSSION}

The solubility of SAHA and LAQ was fairly low in $\mathrm{ddH}_{2} \mathrm{O}(0.16 \mathrm{mg} / \mathrm{mL}$ for SAHA and $0.008 \mathrm{mg} / \mathrm{mL}$ for LAQ at $\mathrm{pH}$ 6), but both drugs became more soluble under alkaline conditions $(4.8 \mathrm{mg} / \mathrm{mL}$ for
SAHA and $3.4 \mathrm{mg} / \mathrm{mL}$ for LAQ at $\mathrm{pH} 12$ ) due to the ability of the hydroxamic acid moiety to deprotonate and form a salt with cations present in the solution. Indeed, SAHA was previously dissolved in alkaline aqueous solution for a phase I clinical trial in order to solubilize a sufficient dose of the drug for I.V. infusion (11), however this formulation approach is not optimal due to potential for precipitation of the drug at the site of injection and disturbance of the plasma $\mathrm{pH}$ balance. Next, we observed that in the presence of excess $\mathrm{FeCl}_{3}$, both SAHA and LAQ exhibited increased aqueous solubility $(2.6 \mathrm{mg} / \mathrm{mL}$ for SAHA and $4.2 \mathrm{mg} / \mathrm{mL}$ for LAQ), and the solutions turned a dark purple or brown color; this color change is indicative of complex formation between $\mathrm{Fe}$ and drug molecules. In the study of reaction stoichiometry between HDACi and Fe, it is important to note that there are six binding sites on Fe(III) and that hydroxamic acid is a bidentate ligand, therefore each $\mathrm{Fe}$ (III) ion should theoretically be able to complex a maximum of three drug molecules (e.g. SAHA, LAQ). Although we observed maximum UV-Vis absorption at 1:1 molar ratio of SAHA/LAQ to Fe(III), the assay cannot distinguish between the various other possible stoichiometries that can indeed form (e.g. $2: 1$ or $3: 1$ ) when the mole ratio of SAHA/LAQ exceeds that of $\mathrm{Fe}(\mathrm{III})$ in solution after the point of intersection on Fig. 2c, 2d. However, these experiments confirm that when SAHA/LAQ is mixed with $\mathrm{Fe}(\mathrm{III})$ at equal molar ratio, a 1:1 stoichiometric complex forms that is characterized by binding constants on the order of $10^{4} \mathrm{M}^{-1}$. Molar ratios of $\mathrm{HDACi}$ to $\mathrm{Fe}$ were kept at 1:1 for all subsequent studies.

For the preparation of PEGylated liposomes (although liposome particle sizes are largely determined by the extrusion process during which all the particles are forced through $100 \mathrm{~nm}$ pores), the final particle size and morphology are also affected by the hydration media and encapsulated contents therefore final liposomes ranged in size from $126 \mathrm{~nm}$ to $171 \mathrm{~nm}$ (Table 2). The higher EE of HDACi-Fe complexes in liposomes compared to SAHA or LAQ drug alone may have been due to the use of methanol in the preparation of liposomal HDACi-Fe which could have helped increase the unit capture volume $(24,25)$, and may also be explained by the seemingly higher affinity of HDACi-Fe complexes for the lipid membrane as evidenced by their slightly lower zetapotentials compared to L-SAHA and L-LAQ. 
(a)

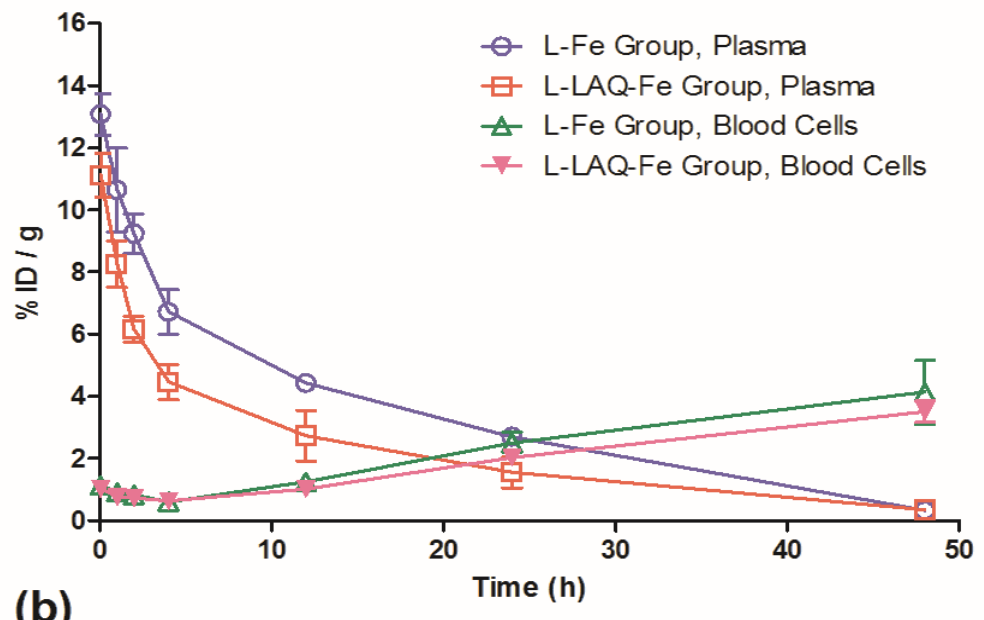

(b)

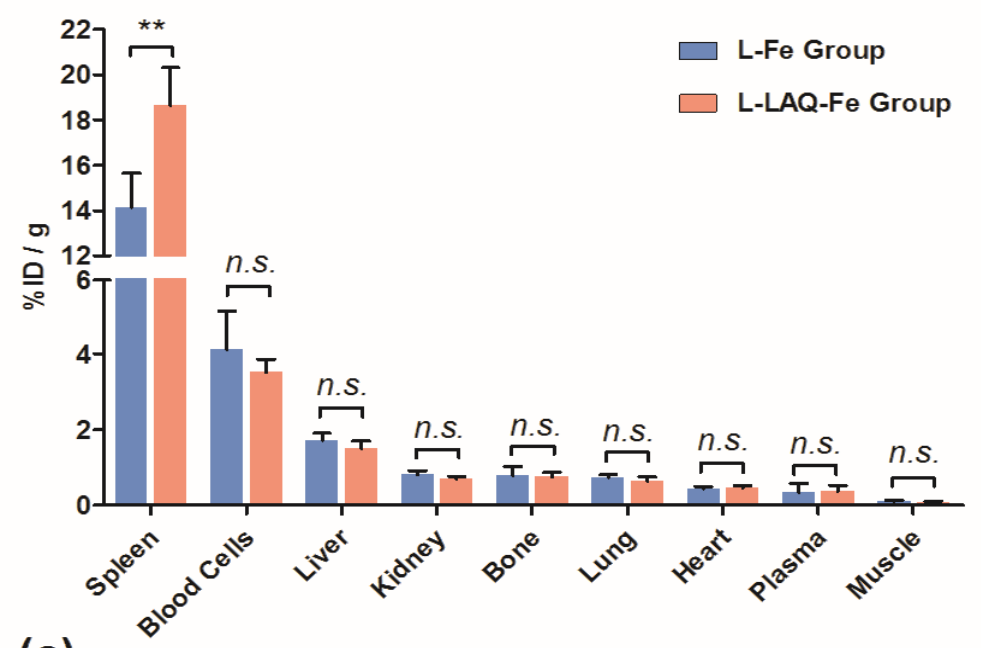

(c)

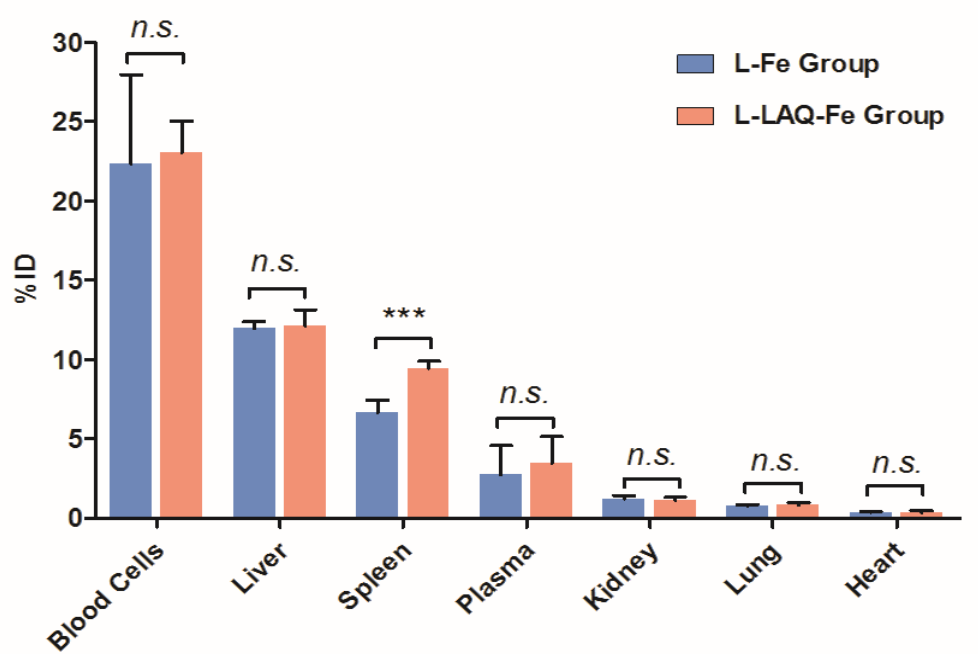

Figure. $8 \mathrm{PK}$ and biodistribution of radioactive Fe-59 in L-Fe and L-LAQ-Fe after I.V. bolus administration to rats ( $\mathrm{n}=5$, mean $\pm \mathrm{SD}$ ). Each injection into animals contained 6-7 $\mu \mathrm{Ci}$ of radioactivity. Plotted is the time course of $\% \mathrm{ID} / \mathrm{g}$ of plasma and blood cells as a function of time (a), the biodistribution of Fe-59 as \% ID/g (b), and biodistribution of Fe-59 as \%ID per whole organ (c); "n.s." stands for not significant; ** $\mathrm{p}<0.01$, *** $\mathrm{p}<0.001$. Plasma $t_{1 / 2}$ of Fe-59 in both L-Fe and L-LAQFe were calculated with PKSolver based on non-compartmental analysis. 
Although presence of free $\mathrm{Fe}(\mathrm{III})$ ions is known to be toxic to cells (26), we found that this required a very high concentration $\left(I C_{50}=4.8 \mathrm{mM}\right)$ in the medium before growth of cells became $50 \%$ inhibited in vitro (Fig. 4 and Table 3). In sharp contrast, the $I C_{50}$ of L-Fe was found to be $38 \mu \mathrm{M}$, meaning that it's 100 times more potent than free $\mathrm{FeCl}_{3}$. This drastic difference is mostly due to the ability of liposomes to carry a large quantity of Fe(III) ions into cells via endocytosis or membrane fusion (27), leading to rapid disturbances of cellular homeostatic processes. This implies that a critical Fe threshold value in cells is required before dramatic inhibition of cellular metabolic processes. At the concentrations tested, Fe complexed to SAHA or LAQ in liposomes did not appear to dramatically contribute to overall cellular growth inhibition although there were some differences in the $I C_{50}$ s for L-LAQ and L-LAQ-Fe (108 vs. $18 \mathrm{nM}$ ) (Fig. 3d). To investigate this further, we proceeded to treat cells with the different formulations and monitored ROS levels.

HDACi have been reported to arrest cancer cell growth by activation of various possible apoptotic pathways (7). One mechanism involves inducing DNA damage and genomic instability in cells by generating ROS and promoting acetylation and repression of DNA damage repair proteins (28). Specifically, SAHA has been reported to induce ROS in prostate cancer cells (including PC-3), eventually leading to cell death via apoptosis (29). LAQ has also been reported to induce apoptosis in leukemia cells due to increased ROS production (30). Similarly metals such as Fe(III) can generate ROS in cells due to the Fenton reaction, causing oxidative stress and damage to cells (26). Although we confirmed that apoptosis was the major mechanism of cell death by HDACi or HDACi-Fe treatments (Fig. 6), our experiments (Fig. 5) have shown that cell viability of PC-3 cells did not appear to correlate directly with ROS production. Overall, the data suggests that alternative mechanisms other than ROS generation are responsible for the induction of apoptotic cell death.

Since L-LAQ-Fe displayed the most promising formulation properties in vitro compared to LSAHA-Fe (the physical 50\% release half-life was ca. 2 days for L-LAQ-Fe and ca. $3 \mathrm{~h}$ for L-SAHA-Fe), we opted to investigate the PK properties of the LAQ formulation in healthy female Sprague Dawley rats. Both L-LAQ and L-LAQ-Fe improved the PK properties of the drug compared to free LAQ (Fig. 7 and Table 4). The plasma $t_{1 / 2}$ that we obtained for free LAQ $(0.79 \mathrm{~h})$ is comparable to previously reported value $(0.2 \mathrm{~h})(13)$. The $t_{1 / 2}$ of L-LAQ-Fe $(12.11 \mathrm{~h})$ that we obtained is also similar to that obtained for the immunoliposome formulation of LAQ $(10.8 \mathrm{~h})$, which is the best formulation for LAQ that has been reported in the literature (13). The clearance of LAQ from the blood is dependent on three processes: (1) clearance of the liposome carrier itself, (2) release of LAQ from the liposomes, and (3) clearance and metabolism of free LAQ released from liposomes (31). Since we know that the liposome carriers of L-LAQ and L-LAQ-Fe should be cleared from blood circulation at similar rates, the stark difference between the plasma $t_{1 / 2}$ of LAQ in these two formulations can most likely only be explained by the difference between rates of LAQ release from liposomes (Fig. 3b). A separate study using radioactive $\mathrm{Fe}-59$ in the L-LAQ-Fe formulation to track PK properties of the iron revealed that $\mathrm{Fe}-59$ had a similar plasma $t_{1 / 2}(11.83 \mathrm{~h})$ (Fig. 8) to that of LAQ in L-LAQ-Fe (12.11 h) (Fig. 7); we also found that the plasma $t_{1 / 2}$ of L-Fe-59 was $9.85 \mathrm{~h}$ which is statistically similar to that found for radioactive LLAQ-Fe, $p>0.05$ (Fig. 8). In essence, although rates of LAQ and $\mathrm{Fe}$ release occurred at different timescales in our in vitro release studies (Fig. 3b), it appears that in vivo both LAQ and Fe released from liposomes at similar rates during circulation. First pass metabolism of the formulation after I.V. administration into animals can lead to rapid uptake/opsonization of liposomes by Kupffer cells in the liver and by macrophages in other major clearance organs such as the spleen (e.g. the mononuclear phagocyte system) (32). Furthermore, because iron can be recycled by mammals as needed by the body, any Fe released from liposomes during circulation may also have been picked up by transferrin and subsequently redistributed into functional (bone marrow and erythrocytes) and storage organs (liver) (33). Indeed, spleen, blood cells, and liver were identified as the major organs/tissues of Fe-59 distribution (Fig. 8b, 8c).

\section{CONCLUSION}

In this work, we investigated whether the hydroxamic acid moiety present in SAHA and LAQ could be used to entrap the drugs in liposomes via formation of a complex with $\mathrm{Fe}$. We found that complex formation with Fe dramatically improved aqueous solubility of the drugs (16-fold for SAHA 
and 525-fold for LAQ) and slowed down release kinetics of drugs from liposomes, without $\mathrm{Fe}$ in the formulation compromising the pro-apoptotic activity of the drugs. The PK of L-LAQ-Fe was evaluated in rats, revealing 15 -fold improvement in the plasma $t_{1 / 2}$ and 211-fold improvement in the $\mathrm{AUC}_{\infty}$ with respect to free LAQ. The fate of radioactive Fe-59 in the LLAQ-Fe formulation was monitored in a separate PK study and its plasma $t_{1 / 2}$ was determined to be 11.83 $\mathrm{h}$ similar to the $t_{1 / 2}$ of $9.85 \mathrm{~h}$ for L-Fe. The majority of Fe-59 activity was found in liver and spleen of rats and correlates with liposomal uptake by the mononuclear phagocyte system. The strategy of metal complexation to improve solubility, liposome encapsulation/release properties, and PK parameters could potentially be applied to a wide range of drug molecules possessing metal-binding moieties.

\section{ACKNOWLEDGMENTS}

We are grateful to Dr. Arvinder Kapur and Prof. Manish Patankar (Dept. of Obstetrics \& Gynecology, University of Wisconsin-Madison), and the UWCCC Flow Cytometry Laboratory for assistance with the flow cytometry data acquisition and analyses. We would also like to acknowledge Dr. Cameron Scarlett (Analytical Instrumentation Center, School of Pharmacy, UW-Madison) for invaluable assistance with the LC-MS method development. We are also grateful to Dr. Jamey Weichert (Dept. of Radiology, UW-Madison) for helpful discussions related to Fe-59 and Justin Jeffrey (Dept. of Radiology) for rat accommodations in the Small Animal Imaging Facility at the Wisconsin Institute for Medical Research. This research was supported by NIH grants R00 CA136970, R01 DK099596, and startup funds from the University of Wisconsin-Madison, School of Pharmacy.

\section{CONFLICT OF INTEREST}

The authors report no conflict of interest.

\section{REFERENCES}

1. Johnstone RW. Histone-deacetylase inhibitors: novel drugs for the treatment of cancer. Nature reviews Drug discovery. 2002;1(4):287-99.

2. Carew JS, Giles FJ, Nawrocki ST. Histone deacetylase inhibitors: mechanisms of cell death and promise in combination cancer therapy. Cancer letters. 2008;269(1):7-17.
3. Inoue $\mathrm{T}$, Hiratsuka $\mathrm{M}$, Osaki $\mathrm{M}$, Oshimura $\mathrm{M}$. The molecular biology of mammalian SIRT proteins: SIRT2 in cell cycle regulation. Cell Cycle. 2007;6(9):1011-8.

4. Pan LN, Lu J, Huang B. HDAC inhibitors: a potential new category of anti-tumor agents. Cellular \& molecular immunology. 2007;4(5):337-43.

5. Cote S, Rosenauer A, Bianchini A, Seiter K, Vandewiele J, Nervi C, et al. Response to histone deacetylase inhibition of novel PML/RARalpha mutants detected in retinoic acid-resistant APL cells. Blood. 2002;100(7):2586-96.

6. Pandolfi PP. Transcription therapy for cancer. Oncogene. 2001;20(24):3116-27.

7. Marks PA. The clinical development of histone deacetylase inhibitors as targeted anticancer drugs. Expert opinion on investigational drugs. 2010;19(9):1049-66.

8. Gaymes TJ, Padua RA, Pla M, Orr S, Omidvar N, Chomienne $\mathrm{C}$, et al. Histone deacetylase inhibitors (HDI) cause DNA damage in leukemia cells: a mechanism for leukemia-specific HDI-dependent apoptosis? Molecular cancer research : MCR. 2006;4(8):563-73.

9. Wagner JM, Hackanson B, Lubbert M, Jung M. Histone deacetylase (HDAC) inhibitors in recent clinical trials for cancer therapy. Clinical epigenetics. 2010;1(3-4):117-36.

10. de Bono JS, Kristeleit R, Tolcher A, Fong P, Pacey S, Karavasilis V, et al. Phase I pharmacokinetic and pharmacodynamic study of LAQ824, a hydroxamate histone deacetylase inhibitor with a heat shock protein-90 inhibitory profile, in patients with advanced solid tumors. Clinical cancer research : an official journal of the American Association for Cancer Research. 2008;14(20):6663-73.

11. Kelly WK, Richon VM, O'Connor O, Curley T, MacGregor-Curtelli B, Tong W, et al. Phase I clinical trial of histone deacetylase inhibitor: Suberoylanilide hydroxamic acid administered intravenously. Clinical Cancer Research. 2003;9(10):3578-88.

12. Mohamed EA, Zhao Y, Meshali MM, Remsberg CM, Borg TM, Foda AM, et al. Vorinostat with sustained exposure and high solubility in poly(ethylene glycol)b-poly(DL-lactic acid) micelle nanocarriers: characterization and effects on pharmacokinetics in rat serum and urine. Journal of pharmaceutical sciences. 2012;101(10):3787-98.

13. Drummond DC, Marx C, Guo Z, Scott G, Noble C, Wang D, et al. Enhanced pharmacodynamic and antitumor properties of a histone deacetylase inhibitor encapsulated in liposomes or ErbB2-targeted immunoliposomes. Clinical cancer research : an official journal of the American Association for Cancer Research. 2005;11(9):3392-401.

14. Ramsay E, Alnajim J, Anantha M, Taggar A, Thomas A, Edwards $\mathrm{K}$, et al. Transition metal-mediated 
liposomal encapsulation of irinotecan (CPT-11) stabilizes the drug in the therapeutically active lactone conformation. Pharmaceutical research. 2006;23(12):2799-808.

15. Ramsay E, Alnajim J, Anantha M, Zastre J, Yan H, Webb $\mathrm{M}$, et al. A novel liposomal irinotecan formulation with significant anti-tumour activity: use of the divalent cation ionophore A23187 and coppercontaining liposomes to improve drug retention. European journal of pharmaceutics and biopharmaceutics : official journal of Arbeitsgemeinschaft fur Pharmazeutische Verfahrenstechnik eV. 2008;68(3):607-17.

16. Thomas AM, Kapanen AI, Hare JI, Ramsay E, Edwards K, Karlsson G, et al. Development of a liposomal nanoparticle formulation of 5-fluorouracil for parenteral administration: formulation design, pharmacokinetics and efficacy. Journal of controlled release : official journal of the Controlled Release Society. 2011;150(2):212-9.

17. Miller MJ. Syntheses and Therapeutic Potential of Hydroxamic Acid Based Siderophores and Analogs. Chem Rev. 1989;89(7):1563-79.

18. Musier KM, Hammes GG. Assessment of the number of nucleotide binding sites on chloroplast coupling factor 1 by the continuous variation method. Biochemistry. 1988;27(18):7015-20.

19. Kolaylı S, Ocak M, Küçük M, Abbasoğlu R. Does caffeine bind to metal ions? Food Chemistry. 2004;84(3):383-8.

20. Carter P. Spectrophotometric determination of serum iron at the submicrogram level with a new reagent (ferrozine). Analytical Biochemistry. 1971;40(2):450-8.

21. O'Brien J, Wilson I, Orton T, Pognan F. Investigation of the Alamar Blue (resazurin) fluorescent dye for the assessment of mammalian cell cytotoxicity. Eur J Biochem. 2000;267(17):5421-6.

22. Wang H, Joseph JA. Quantifying cellular oxidative stress by dichlorofluorescein assay using microplate reader. Free radical biology \& medicine. 1999;27(56):612-6.

23. Zhang Y, Huo M, Zhou J, Xie S. PKSolver: An addin program for pharmacokinetic and pharmacodynamic data analysis in Microsoft Excel. Computer methods and programs in biomedicine. 2010;99(3):306-14.

24. Szoka F, Jr., Papahadjopoulos D. Procedure for preparation of liposomes with large internal aqueous space and high capture by reverse-phase evaporation. Proc Natl Acad Sci U S A. 1978;75(9):4194-8.

25. Perkins WR, Minchey SR, Ahl PL, Janoff AS. The determination of liposome captured volume. Chem Phys Lipids. 1993;64(1-3):197-217.

26. Eaton JW, Qian M. Molecular bases of cellular iron toxicity. Free radical biology \& medicine. 2002;32(9):833-40.

27. Düzgüneş N, Nir S. Mechanisms and kinetics of liposome-cell interactions. Advanced Drug Delivery Reviews. 1999;40(1-2):3-18.

28. Eot-Houllier G, Fulcrand G, Magnaghi-Jaulin L, Jaulin C. Histone deacetylase inhibitors and genomic instability. Cancer letters. 2009;274(2):169-76.

29. Xu W, Ngo L, Perez G, Dokmanovic M, Marks PA. Intrinsic apoptotic and thioredoxin pathways in human prostate cancer cell response to histone deacetylase inhibitor. Proc Natl Acad Sci U S A. 2006;103(42):15540-5.

30. Rosato RR, Almenara JA, Maggio SC, Coe S, Atadja $\mathrm{P}$, Dent $\mathrm{P}$, et al. Role of histone deacetylase inhibitorinduced reactive oxygen species and DNA damage in LAQ-824/fludarabine antileukemic interactions. Molecular cancer therapeutics. 2008;7(10):3285-97.

31. Drummond DC, Noble CO, Hayes ME, Park JW, Kirpotin DB. Pharmacokinetics and in vivo drug release rates in liposomal nanocarrier development. Journal of pharmaceutical sciences. 2008;97(11):4696-740.

32. Allen TM, Hansen C, Rutledge J. Liposomes with prolonged circulation times: factors affecting uptake by reticuloendothelial and other tissues. Biochimica et biophysica acta. 1989;981(1):27-35.

33. Andrews NC. Disorders of iron metabolism. The New England journal of medicine. 1999;341(26):1986-95. 


\section{Supplementary Information}

1. Measurement of HDACi-Fe binding constants was conducted following a reported method (1). The equilibrium between HDACi and $\mathrm{Fe}(\mathrm{III})$ in the solution is:

$$
\mathrm{HDACi}+\mathrm{Fe}(\mathrm{III}) \leftrightarrow \mathrm{HDACi} \cdot \mathrm{Fe}(\mathrm{III})
$$

The binding constant of HDACi-Fe is defined in Eq. (2):

$$
k=\frac{[\mathrm{HDACi} \cdot \mathrm{Fe}(\mathrm{III})]}{[\mathrm{HDACi}] \times[\mathrm{Fe}(\mathrm{III})]}
$$

According to Klotz plots (2), the following Eq. (3) should be used to determine the binding constants of HDACi-Fe complexes, where $c$ is the concentration of HDACi-Fe complex, $n$ is the number of metal binding sites on HDACi $(n=$ 1 for both SAHA and LAQ), $a$ is HDACi concentration, $L$ is total $\mathrm{Fe}(\mathrm{III})$ concentration and $k$ is binding constant:

$$
\frac{1}{c}=\frac{1}{n \times a \times k} \times \frac{1}{L}+\frac{1}{n \times a}
$$

The absorbance of HDACi-Fe complex $\left(A_{\mathrm{c}}\right)$ at $500 \mathrm{~nm}$ can be used to substitute $c$ by multiplying it with the inverse of extinction coefficient of the complex, $1 / \varepsilon$, to obtain Eq. (4):

$$
\frac{1}{A_{\mathrm{c}} \times \frac{1}{\varepsilon}}=\frac{1}{n \times a \times k} \times \frac{1}{L}+\frac{1}{n \times a}
$$

By dividing $\varepsilon$ on both sides of Eq. (4), Eq. (5) is obtained:

$$
\frac{1}{A_{\mathrm{c}}}=\frac{1}{\varepsilon \times n \times a \times k} \times \frac{1}{L}+\frac{1}{\varepsilon \times n \times a}
$$

Plot $1 / A_{\mathrm{c}}$ against $1 / L$, and the binding constant $k$ (unit M-1) can be calculated as the ratio of the intercept on the vertical axis to the slope:

$$
k=\frac{\frac{1}{\varepsilon \times n \times a}}{\frac{1}{\varepsilon \times n \times a \times k}}=\frac{\text { intercept on vertical axis }}{\text { slope }}
$$

2. Typical LC-MS chromatogram with SAHA as internal standard and LAQ the analyte. The detection was conducted by monitoring the fragmentation of $\mathrm{m} / \mathrm{z} 380.1 \rightarrow 176.0,144.1,115.0$ for LAQ and $\mathrm{m} / \mathrm{z} 265.1 \rightarrow 232.1,172.1,94.0$ for internal standard SAHA. LAQ eluted at around 2.23 minutes, and SAHA eluted at around 3.23 minutes.

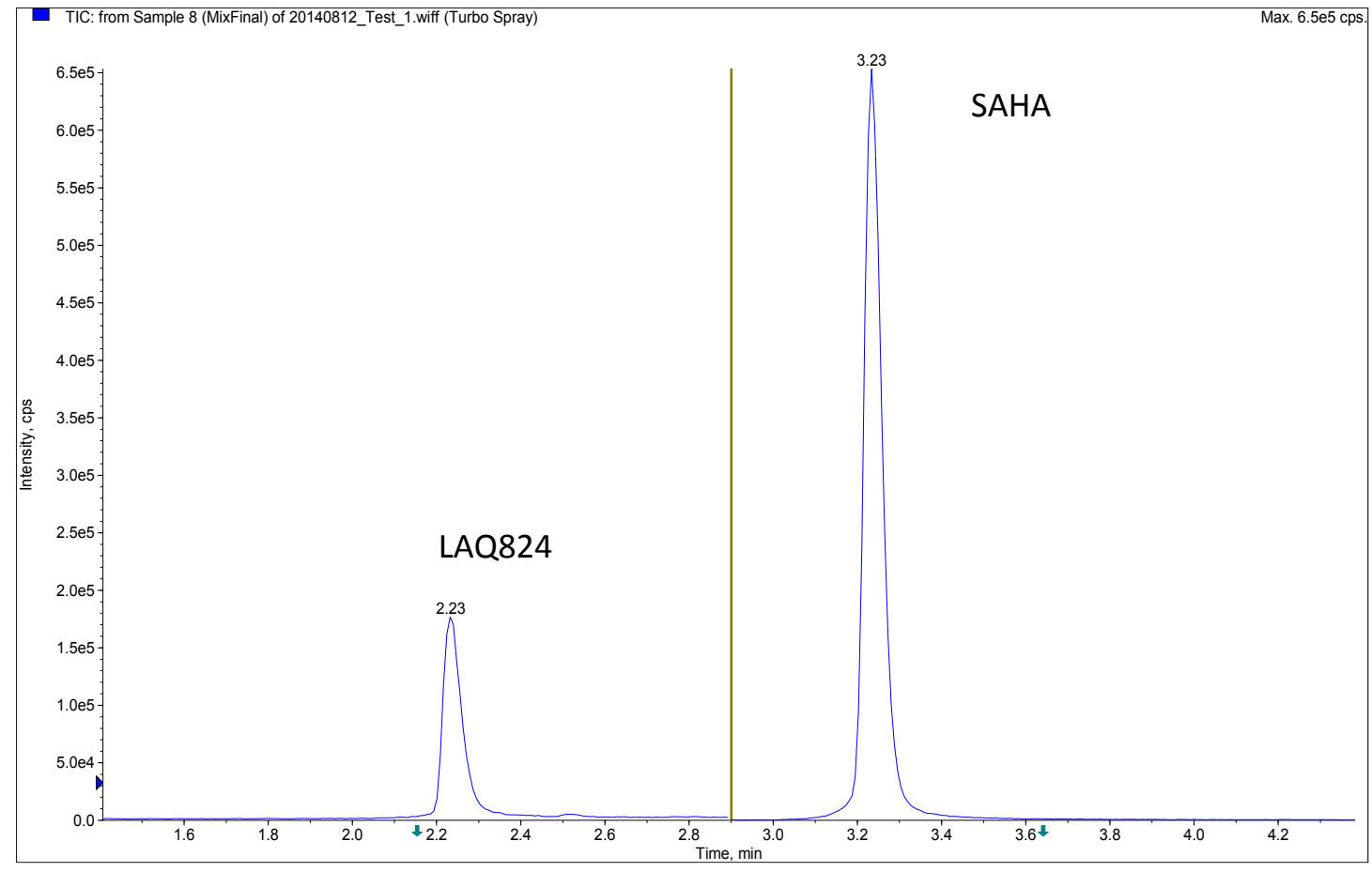


3. LC-MS calibration curve for LAQ at the range 1-500 ng/ml. Standard concentrations are 1, 3, 10, 30, 100, 500 ng/ml. The calibration was fitted with quadratic function with weighting of $1 /(\mathrm{x})$ and $\mathrm{r}^{2}>0.999$.

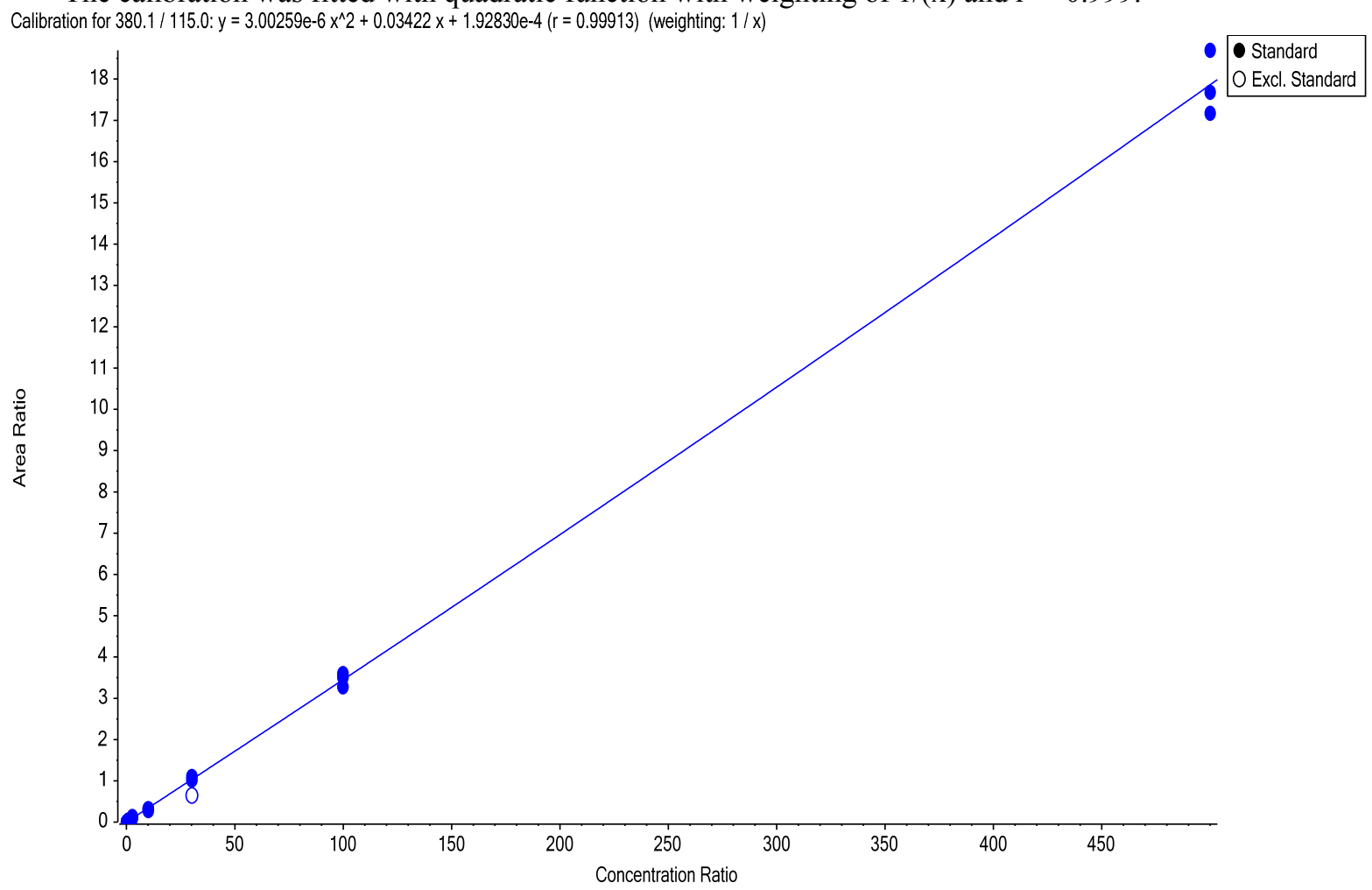

\section{Reference}

1. Kolayli S, Ocak M, Kucuk M, Abbasoglu R. Does caffeine bind to metal ions? Food Chem. 2004;84(3):383-8.

2. Klotz IM, Hunston DL. Properties of Graphical Representations of Multiple Classes of Binding Sites. BiochemistryUs. 1971;10(16):3065-9. 